\title{
Occurrence of Human Enteric Viruses in Water Sources and Shellfish: A Focus on Africa
}

\author{
Nicole S. Upfold ${ }^{1}\left(\mathbb{D} \cdot\right.$ Garry A. Luke ${ }^{2}$ (D) $\cdot$ Caroline Knox $^{1}(\mathbb{D}$
}

Received: 5 September 2020 / Accepted: 16 December 2020 / Published online: 27 January 2021

(c) The Author(s), under exclusive licence to Springer Science+Business Media, LLC part of Springer Nature 2021

\begin{abstract}
Enteric viruses are a diverse group of human pathogens which are primarily transmitted by the faecal-oral route and are a major cause of non-bacterial diarrhoeal disease in both developed and developing countries. Because they are shed in high numbers by infected individuals and can persist for a long time in the environment, they pose a serious threat to human health globally. Enteric viruses end up in the environment mainly through discharge or leakage of raw or inadequately treated sewage into water sources such as springs, rivers, dams, or marine estuaries. Human exposure then follows when contaminated water is used for drinking, cooking, or recreation and, importantly, when filter-feeding bivalve shellfish are consumed. The human health hazard posed by enteric viruses is particularly serious in Africa where rapid urbanisation in a relatively short period of time has led to the expansion of informal settlements with poor sanitation and failing or non-existent wastewater treatment infrastructure, and where rural communities with limited or no access to municipal water are dependent on nearby open water sources for their subsistence. The role of sewage-contaminated water and bivalve shellfish as vehicles for transmission of enteric viruses is well documented but, to our knowledge, has not been comprehensively reviewed in the African context. Here we provide an overview of enteric viruses and then review the growing body of research where these viruses have been detected in association with sewage-contaminated water or food in several African countries. These studies highlight the need for more research into the prevalence, molecular epidemiology and circulation of these viruses in Africa, as well as for development and application of innovative wastewater treatment approaches to reduce environmental pollution and its impact on human health on the continent.
\end{abstract}

Keywords Enteric viruses $\cdot$ Gastroenteritis $\cdot$ Wastewater $\cdot$ Shellfish $\cdot$ African continent

\section{Introduction}

Enteric viruses collectively represent a diverse group of pathogens that are responsible for a variety of notifiable diseases in humans through ingestion of contaminated food or water. Well-known human pathogens in this group are members of the Caliciviridae (e.g. norovirus), Picornaviridae (e.g. enterovirus, Aichi virus, hepatitis A virus), Hepeviridae (e.g. hepatitis E virus), Reoviridae (e.g. rotavirus), Astroviridae (astrovirus) and Adenoviridae

Caroline Knox

caroline.knox@ru.ac.za

1 Department of Biochemistry and Microbiology, Rhodes University, Grahamstown 6140, South Africa

2 Centre for Biomolecular Sciences, School of Biology, Biomolecular Sciences Building, University of St Andrews, North Haugh, St Andrews, Scotland KY16 9ST, UK (e.g. adenovirus 40, 41) (Fong and Lipp 2005; Bishop and Kirkwood 2008). These viruses are a major public health concern globally due to the fact that they tend to be stable in the environment, are shed at high concentrations in the faeces of infected people and are transmitted by the faecal-oral route (Fong and Lipp 2005; Sánchez and Bosch 2016; Bouseettine et al. 2019). Although these viruses are known to occur naturally in aquatic environments, one of the greatest risks they pose to public health arises from discharge of either raw (untreated) sewage or inadequately treated wastewater into ground or surface water sources utilised by humans for various activities including drinking, recreation, or consumption of foods such as molluscan bivalve shellfish harvested from polluted rivers or marine estuaries. Isolation of enteric viruses from such sewagecontaminated water sources and association of disease outbreaks as a result of human exposure to them are well documented in the literature (see for example: Lees 2000; 
Okoh et al. 2010; Gibson 2014; Richards 2016; Khora 2018; Masciopinto et al. 2019).

Transmission of enteric viruses to humans is particularly concerning in developing countries of the world where it is estimated that $80-90 \%$ of untreated sewage is disposed into water sources such as rivers, streams and other aquatic ecosystems causing environmental pollution (WWAP and UNESCO 2017; Fayomi et al. 2019). Countries in Africa and especially those in the Sub-Saharan region where it is estimated that $55 \%$ of urban dwellers now live in informal settlements are most at risk from infectious diseases because of overcrowding and poor sanitation infrastructure (Neiderud 2015; Boyce et al. 2019; Weimann and Oni 2019). Furthermore, people living in rural communities and informal settlements in Africa often rely on environmental surface and ground water sources polluted by wastewater and other contaminants originating from human activities for drinking, cooking and washing (Wang et al. 2014; Sibanda et al. 2015; Pichel et al. 2019; UNESCO 2019). Growing concern about the human health impact of environmental pollution, in particular untreated sewage discharge into fresh and marine aquatic systems, has led to numerous studies describing the isolation and molecular detection of enteric viruses in water and food sources and their association with disease outbreaks in several African countries. For example, these viruses have been reported in bivalve shellfish and environmental water sources in North Africa (Morocco, Tunisia and Egypt) (Benabbes et al. 2013b; Zormati et al. 2018; Shaheen and Elmahdy 2019) as well as in several Sub-Saharan countries including Chad (Guerrero-Latorre et al. 2011), Nigeria (Adeniji and Faleye 2014), Ghana (Lutterodt et al. 2018), Côte d'Ivoire (Momou et al. 2017), Benin (Verheyen et al. 2009), Kenya (Kiulia et al. 2014), Uganda (Katukiza et al. 2013b), Tanzania (Mattioli et al. 2014), Mozambique (Nenonen et al. 2006) and South Africa (Chigor et al. 2014; Onosi et al. 2020). Although the role of enteric viruses in food- and waterborne disease transmission has been extensively reviewed for the developed world (Lipp and Rose 1997; Potasman et al. 2002; Sinclair et al. 2009; Westrell et al. 2010; Bellou et al. 2013; Romalde et al. 2017; Meghnath et al. 2019) and Egypt (Aboubakr and Goyal 2019), to our knowledge, a review of the African continent where people are most at risk from exposure to these viruses is not available. Here, we present an overview of enteric viruses and then review what is known about bivalve shellfish and sewage-contaminated water sources as possible vehicles for transmission in African countries, with a view to highlighting the importance of further studies investigating the true prevalence, molecular epidemiology and circulation of these important human pathogens on the continent.

\section{Classification, Structure and Biology of Enteric Viruses}

Enteric viruses encompass a broad range of viral pathogens which infect the human gastrointestinal tract, causing a wide variety of diseases and symptoms (Okoh et al. 2010). Commonly studied enteric viruses are non-enveloped and display high levels of stability in the environment (Fong and Lipp 2005; Alidjinou et al. 2019). Most enteric viruses have RNA genomes and belong to the Reoviridae (ds: double-stranded), Astroviridae, Caliciviridae, Hepeviridae or Picornaviridae (ss: single-stranded) families, while enteric viruses with DNA genomes are members of the Adenoviridae (ds) or Parvoviridae (ss).

\section{Rotaviruses}

Globally, rotaviruses (RVs; family Reoviridae) are a major cause of severe viral gastroenteritis in the paediatric population (Bányai et al. 2018) and account for a significant proportion of diarrhoea-related deaths among children under the age of five (29.3\% in 2015) (Wang et al. 2016). The introduction of RV vaccines has, however, reduced the burden of associated gastroenteritis in many countries (Troeger et al. 2018; Aliabadi et al. 2019), including those within sub-Saharan Africa (Tate et al. 2016; Godfrey et al. 2020). The RV genome consists of 11 dsRNA segments encoding six structural (VP1-4, 6 and 7) and six non-structural (NSP1-NSP6) proteins (Crawford et al. 2017; Gómez-Rial et al. 2020). Based on antigenic differences and the diversity of the VP6 capsid protein sequence, RVs are classified into ten species (A-J), of which species A, B, C and H cause human RV infections. Group A is the predominant cause of $\mathrm{RV}$-gastroenteritis and is further classified into $32 \mathrm{G}$ and 47 $P$ genotypes based on differences in the sequences encoding the surface exposed capsid proteins VP7 (G antigen) and VP4 (P antigen) (Crawford et al. 2017), respectively. Various $\mathrm{G}$ and $\mathrm{P}$ combinations have been identified, however, genotypes G1P[8], G2P[4], G3P[8], G4P[8], G9P[8] and G12P[8] are more commonly detected worldwide (Bányai et al. 2018). RV genotypes isolated from wastewater correspond to those reported in clinical samples from the same regions (Sdiri-Loulizi et al. 2010a; Prez et al. 2020), thus environmental monitoring provides useful data on the epidemiology of RVs circulating within populations (Abdel-Daim et al. 2019).

\section{Caliciviruses: Noroviruses and Sapoviruses}

Noroviruses (NoVs; family Caliciviridae) are currently recognised as the leading cause of sporadic and epidemic 
viral gastroenteritis globally, resulting in approximately 677 million infections per annum (Pires et al. 2015; De Graaf et al. 2016). NoV-associated gastroenteritis is usually self-limiting, although prolonged symptoms and secondary complications can arise in young children, the elderly and individuals with impaired immunity (Trivedi et al. 2013; Petrignani et al. 2018). The NoV genome is organised into three open reading frames (ORF1-3) encoding a large nonstructural polyprotein (cleaved into six proteins), the major VP1 capsid protein and the minor VP2 capsid protein (De Graaf et al. 2016), respectively. Reverse transcription polymerase chain reaction (RT-PCR) and quantitative real-time PCR (RT-qPCR) assays targeting the ORF1-ORF2 junction region have become standard in the detection and quantification of NoV from clinical and environmental samples. NoVs display a wide degree of genetic and antigenic variability and can be classified into different genogroups (GI-GX) as well as $\mathrm{P}$ groups based on amino acid diversity of the complete VP1 gene and nucleotide diversity of the viral polymerase sequence (Kroneman et al. 2013; Chhabra et al. 2019), respectively. Human NoV infections are predominantly caused by the genogroups GI and GII, with GII.4 variants causing most cases in the last decade (Siebenga et al. 2009; Vinjé 2015; Mans et al. 2016). In 2014, a novel variant of genotype GII.17 (GII.P17-GII.17) emerged as a major cause of NoV-associated gastroenteritis in Asia, and has since been reported globally (Chan et al. 2015; Lu et al. 2015; Chan et al. 2017; Hoa-Tran et al. 2017; Zhou et al. 2019). Genotype GII.4 is most associated with transmission through person-person contact, while strains of Genogroup GI are more closely associated with waterborne transmission (De Graaf et al. 2016). Strains belonging to GIV have been detected in both clinical and environmental samples; however, further studies are needed to fully understand the prevalence, epidemiology and medical significance of this genogroup (Muscillo et al. 2013; Kitajima et al. 2016; Teixeira et al. 2016).

Sapoviruses (SaVs) also belong to the Caliciviridae and are aetiological agents of acute viral gastroenteritis, causing both sporadic and outbreak cases in a variety of settings (Oka et al. 2015). Symptoms are generally milder than those caused by NoV and although infections occur in all age groups, $\mathrm{SaV}$-associated gastroenteritis is more prevalent in children and infants (Liu et al. 2016). The $\mathrm{SaV}$ genome usually contains two ORFs. The first (ORF1) encodes a single non-structural polyprotein and a major capsid protein (VP1), while a smaller capsid protein (VP2) is encoded by ORF2 (Makhaola et al. 2020). SaVs are routinely detected by RT-PCR of the VP1 or polymerase encoding regions, and genotyping is based on differences within the VP1coding sequence (Hansman et al. 2007; Oka et al. 2015). $\mathrm{SaVs}$ are phylogenetically clustered into 19 genogroups, of which GI, GII, GIV and GV contain human SaVs and are further subdivided into genotypes GI.1-GI.7, GII.1-GII.8, GIV.1 and GV.1-GV.2 (Oka et al. 2015; Diez-Valcarce et al. 2018; Makhaola et al. 2020). Globally, strains belonging to genogroups GI and GII are more prevalent than SaVs belonging to genogroups GIV and GV (Fioretti et al. 2016; Yoneda et al. 2017; Mann et al. 2019; Supadej et al. 2019; Varela et al. 2019). Recently, GI was confirmed as the most prevalent genogroup detected in people and the environment within African countries (Makhaola et al. 2020).

\section{Astroviruses}

Human Astroviruses (HAstVs; family Astroviridae) are common aetiological agents of acute paediatric gastroenteritis, after rotavirus and the caliciviruses (Platts-Mills et al. 2015; Vu et al. 2017; Wohlgemuth et al. 2019), and are detected at rates comparable to adenoviruses in cases of paediatric diarrhoea (Andreasi et al. 2008; Levidiotou et al. 2009; Hamkar et al. 2010; Akdag et al. 2020). HAstV-associated gastroenteritis is also reported in the adult population, particularly in the elderly and individuals with compromised immunity (Vu et al. 2017; Wohlgemuth et al. 2019). More recently, HAstVs have become associated with central nervous system (CNS) infections such as encephalitis and acute flaccid paralysis, in immunocompromised individuals (Cordey et al. 2016; Vu et al. 2016). The HastV genome contains three ORFs. ORF1a and $1 \mathrm{~b}$ encode the non-structural proteins involved in viral replication, while ORF2 encodes the capsid proteins, which are expressed on a sub-genomic RNA (Bosch et al. 2014). Astroviruses exhibit a high degree of genetic diversity and infect many host species which has complicated the classification of these viruses. Based on the full-length amino acid sequence of ORF2, HAstVs belong to the species MAstV-1 (HAstV-1-8), MAstV-6 (MLB1-3), MAstV-8 (VA2/HMO-A, VA4, VA5, BF34) and MAstV-9 (VA1/HMO-C, VA3/HMO-B) of the Mamastrovirus genus (reviewed by Donato and Vijaykrishna, 2017). Additionally, classic HAstVs (MAstV-1 strains) have been further typed, according to ORF1a, into genogroups A (HAstv-1, -2, -3, $-4,-5$ and -8 ) and B (HAstv-6 and -7). Globally, HastV-1 strains account for more than half of all recently reported cases (Vu et al. 2017).

\section{Picornaviruses: Enteroviruses, Aichivirus and Hepatitis A Virus}

Enteroviruses (EVs; genus Enterovirus) belong to the family Picornaviridae and include enterically transmitted viruses of clinical significance (Wells and Coyne 2019). EVs infect millions of people globally, causing sporadic and outbreak cases in both developed and low to middle-income countries (Lugo and Krogstad 2016; Cassidy et al. 2018; Smuts et al. 2018; Puenpa et al. 2019). Although infections are usually 
asymptomatic, coxsackieviruses (e.g. CV-A6), echoviruses (e.g. E-30) and enteroviruses (e.g. EV-A71 and EV-D68) cause a broad range of illnesses such as hand-foot-andmouth disease, myocarditis, encephalitis and acute flaccid paralysis, which tend to be more severe in neonates and immunocompromised individuals (Tang and Holmes 2017; Baggen et al. 2018). To date, more than $300 \mathrm{EV}$ types have been identified and are classified within 15 species (Chen et al. 2020). Human EVs belong to seven species, but only four (Enterovirus $A-D$ ) include viruses infecting the gastrointestinal tract (Baggen et al. 2018). Originally, EVs were grouped into serotypes on the basis of the VP1 capsid protein, however, sequence-based methods targeting the VP1 capsid-encoding region are now typically used to classify EV by genetic similarity (Oberste et al. 1999a, 1999b; Nix et al. 2006). RT-PCR-based assays targeting additional sequences such as the 5' untranslated region (UTR) of the genome (Zhou et al. 2011) and the VP2 and VP4 capsid proteins (Royston et al. 2017) have also been developed, but their roles in genotyping are variable (Lindberg et al. 2003; Kottaridi et al. 2004; Nasri et al. 2007; Perera et al. 2010). Globally, many studies have isolated EVs from sewage, fresh surface waters, ground water and seas, highlighting the widespread presence of these viruses in the environment (Rajtar et al. 2008).

Aichi virus (AiV), a subtype of the species Aichivirus A (genus Kobuvirus) (Rivadulla and Romalde 2020), was first isolated in 1989 during an outbreak of oyster-associated gastroenteritis in Japan (Yamashita et al. 1991) and has since been detected worldwide (Oh et al. 2006; Sdiri-Loulizi et al. 2009; Yang et al. 2009; Chuchaona et al. 2017; Bergallo et al. 2018; Kitajima et al. 2018; Japhet et al. 2019; Onosi et al. 2019; Northill et al. 2020). Globally, the incidence rates of $\mathrm{AiV}$ in gastroenteritis cases are low (0.4-6.5\%) (Rivadulla and Romalde 2020; Taghinejad et al. 2020), yet AiV-specific antibodies are present in $80-99 \%$ of the adult population (Kitajima and Gerba 2015) suggesting that most infections are asymptomatic (Bergallo et al. 2018). In addition to the low prevalence of $\mathrm{AiV}$-associated gastroenteritis, the virus is often detected in conjunction with other welldefined enteric pathogens (Oh et al. 2006; Ambert-Balay et al. 2008; Kaikkonen et al. 2010; Japhet et al. 2019). Consequently, the clinical importance of $\mathrm{AiV}$ is unclear (Rivadulla and Romalde 2020), although some studies do support the virus as an enteric pathogen causing gastroenteritis (Yang et al. 2009; Drexler et al. 2011; Rivadulla et al. 2019). Human $\mathrm{AiV}$ is currently divided into three genotypes (A-C), based on differences in the sequences encoding the $\mathrm{C}$-terminus of the $3 \mathrm{C}$ protease and the $\mathrm{N}$-terminus of the 3D RNA-dependent RNA-polymerase (RdRp) (3CD junction) (Yamashita et al. 2000; Kitajima and Gerba 2015). RTPCR-based assays targeting this junction and the VP1 capsid protein are widely used for AiV detection and genotyping
(Oh et al. 2006; Pham et al. 2007; Ambert-Balay et al. 2008; Lodder et al. 2013; Ibrahim et al. 2017a). Genotypes A and $\mathrm{B}$ are prevalent in clinical and environmental samples from Africa, America, Asia and Europe (Rivadulla and Romalde 2020), while genotype $C$ has only ever been detected in one clinical sample from France (Ambert-Balay et al. 2008).

Hepatitis A (HAV) is one of the major aetiological agents of acute hepatitis worldwide, infecting an estimated 1.5 million people per annum (WHO 2017; Lemon et al. 2018). HAV is classified within the Hepatovirus genus of the Picornaviridae family and is subdivided into one serotype and six genotypes, of which three (I-III) infect humans (Smith and Simmonds 2018). Several subtypes have been characterised, but HAV IA, IB, IIIA and IIIB are more commonly detected (Smith and Simmonds 2018). HAV encodes a single polyprotein, which is cleaved into the capsid (VP1Px, VP2-4) and non-structural (2B, 2C and 3A-D) proteins (McKnight and Lemon 2018). RT-PCR-based assays targeting the partial or full-length VP1 capsid protein, VP1-2A(Px) junction and VP1-2A(Px)-2B proteins are widely implemented for the detection and genotyping of HAV (Nainan et al. 2006; Coudray-Meunier et al. 2014).

\section{Hepatitis E Virus}

Hepatitis E Virus (HEV; family Hepeviridae) is classified within the genus Orthohepevirus and species Orthohepevirus $A$ (Denner 2019). Eight genotypes have been characterised (HEV 1-8), although only five (HEV 1-4 and 7) are associated with human infection. Genotypes 1 and 2 are responsible for most sporadic and epidemic cases of hepatitis E, and are highly endemic in certain regions of Africa, Asia and Mexico (Smith and Simmonds 2018). Genotypes 3, 4 and 7 are primarily zoonotic and are more typically associated with sporadic and clustered infections in developed regions (Nimgaonkar et al. 2018). The HEV genome contains three ORFs (ORF1-3), although a fourth, ORF4, is present in genotype 1 (Nimgaonkar et al. 2018). RT-PCRbased assays targeting the full or partial sequences of ORF1 (non-structural proteins) and ORF2 (capsid proteins) are typically used for the molecular characterisation and genotyping of HEV in clinical and environmental samples. However, other genomic regions are sometimes targeted as there is no consensus classification system for the differentiation of HEV genotypes (Al-Sadeq et al. 2018).

\section{Enteric Adenoviruses}

Human adenoviruses (HAdVs; family Adenoviridae) are endemic aetiological agents of enteric, respiratory and ocular diseases that are typically mild and self-limiting, but can develop into severe infections with unusual manifestations in immunocompromised individuals (reviewed by Khanal 
et al., 2018). The global prevalence of enteric HAdVs in childhood diarrhoea varies from $1-8 \%$ and $2-31 \%$ in developed and developing countries (Meqdam and Thwiny 2007; Hassou et al. 2019), respectively. In sub-Saharan Africa, HAdV was detected in approximately $10.8 \%$ of all gastroenteritis cases among children under five years of age between 2007 and 2019 (Oppong et al. 2020). Currently, 103 HAdV types are reported and classified into seven species (A-G) within the Mastadenovirus genus (Kosulin, 2019; Mennechet et al., 2019; Brister et al. 2019). Classification of the first 51 types was based upon serological profiles of the dominant capsid proteins, however, sequence analysis is now the standard method for characterising novel types (Mennechet et al. 2019). The large dsDNA genomes of HAdV encode many genes, including those for the hexon, penton and fibre proteins which constitute most of the viral capsid (Vellinga et al. 2005; Mennechet et al. 2019). PCRbased assays targeting the sequences encoding the hexon and fibre proteins have become the accepted method for HAdV detection, in both clinical and environmental samples (Jiang 2006). HAdV species F, types 40 and 41 account for almost all cases of HAdV-related gastroenteritis. Types within groups $\mathrm{A}, \mathrm{C}, \mathrm{D}$ and $\mathrm{G}$ have been detected in patients presenting with diarrhoea, but potential roles for these viruses in the aetiology of gastroenteritis remain unclear (Lion 2014; Afrad et al. 2018). Studies using next-generation sequencing (NGS) have documented the circulation of a wide range of HAdV species and types in sewage and wastewater in different countries (Ogorzaly et al. 2015; Iaconelli et al. 2017).

\section{Human Bocaviruses}

Human bocaviruses (HBoVs; genus Bocaparvovirus) are recent members of the Parvovirus family and have been detected globally in a variety of clinical samples (Guido et al. 2016). Four HBoVs are described and classified into two species (Primate bocaparvovirus 1 : HBoV-1 and $\mathrm{HBoV}-3$; Primate bocaparvovirus 2: $\mathrm{HBoV}-2$ and $\mathrm{HBoV}-$ 4) (Söderlund-Venermo 2019). HBoV-1 was first isolated from nasopharyngeal aspirates and is associated with respiratory tract infections in children (Christensen et al. 2019). HBoV-2 and HBoV-4 are frequently detected in stools from diarrheic patients (Guido et al. 2016) but also asymptomatic individuals (Paloniemi et al. 2014) and are often found in conjunction with other enteric viruses, such as RV and NoV (Huang et al. 2010; Campos et al. 2016). Consequently, the role of HBoVs in gastroenteritis remains to be clarified (Ong et al. 2016). Several PCR-based assays have been developed for the molecular detection of HBoV DNA in clinical and environmental samples (Lu et al. 2006; Iaconelli et al. 2016; La Rosa et al. 2016, 2018). These assays are specific for the sequences encoding the conserved non-structural protein (NS1) and moderately conserved nuclear phosphoprotein
(NP1), while the hypervariable region encoding the VP1/ VP2 capsid proteins is commonly targeted for the differentiation of genotypes (Guido et al. 2016; Lee et al. 2016; Wagner et al. 2016). Globally, HBoVs have been detected in environmental samples such as sewage wastewater (Blinkova et al. 2009; Iaconelli et al. 2016), river water (La Rosa et al. 2017) and shellfish (La Rosa et al. 2018; Onosi et al. 2020), highlighting potential routes of transmission.

\section{Sewage-Polluted Water and Bivalve Shellfish as Vehicles for Enteric Virus Transmission}

Human enteric viruses are shed at high concentrations $\left(10^{5}-10^{13}\right.$ viral particles per gram of stool) in the faeces of infected individuals (Bosch 1998; Atmar et al. 2008; Drexler et al. 2011; Bosch et al. 2014), with or without illness and often long after the cessation of symptoms (Yotsuyanagi et al. 1996; Shastri et al. 1998; Murata et al. 2007; Takahashi et al. 2007; Kapusinszky et al. 2012; Crawford et al. 2017). Untreated sewage wastewater is therefore a significant source of enteric pathogens and requires decontamination prior to discharge in the environment. However, traditional treatment processes do not completely reduce viral loads as many enteric viruses can withstand physical treatment procedures and disinfectants such as chlorination and UV irradiation (La Rosa et al. 2010; Okoh et al. 2010; Qiu et al. 2015; Sidhu et al. 2018; Prado et al. 2019). Consequently, a high concentration of surviving virions may be discharged into receiving water bodies such as springs, rivers, dams or marine estuaries upon the release of inadequately treated effluent. Alternatively, raw sewage may enter the environment through damaged sewage infrastructure and wet weather overflows such as heavy rainfall events (Ahmed et al. 2020b). Moreover, many developing countries lack adequate sanitation infrastructure altogether, and surrounding water sources are easily contaminated with excreta containing enteric pathogens (Wang et al. 2014; Kayembe et al. 2018; Farkas et al. 2020). Indeed, it is estimated that only $28 \%$ of sewage wastewater is treated prior to discharge into surface waters in low- and middle-income countries (WWAP and UNESCO 2017).

Enteric viruses are highly stable in water environments, particularly when bound to particulate matter (Bosch 1998; Okoh et al. 2010; Seitz et al. 2011). Adsorption to solid particles facilitates the dispersion of viruses along water systems and the settling and accumulation of virions within sediments, where they may persist for prolonged periods (Goyal et al. 1984; Hassard et al. 2016). Disturbance of these sediments releases viruses back into the water column, enabling further dissemination through the water system (Bosch 1998). Enteric viruses have very low infectious doses (Okoh et al. 2010); for example, the 50\% human infectious dose 
(HID) $)_{50}$ of NoV is 18 virus particles, while for RV, only 1 focus forming unit (ffu) is required to infect 25\% of susceptible adults (Yezli and Otter 2011; Hall 2012). Therefore, the use of untreated water from environmental sources often leads to outbreaks of viral diseases, even in cases where contamination is marginal (Sinclair et al. 2009).

The risk of enteric virus transmission arises not only from contact with polluted water but also from the consumption of bivalve shellfish grown and harvested in virus-contaminated waters (Lees 2000; Bellou et al. 2013). Bivalve shellfish (molluscs) including clams, mussels, oysters and scallops are active filter-feeding species that remove and sequester food particles together with a myriad of waterborne microbes. These bivalves sieve many gallons of water a day through their gills, (Burkhardt and Calci 2000; Rice 2001; Greening and Cannon 2016), which can lead to the bioaccumulation of environmentally stable, viral pathogens within shellfish tissues, at concentrations far exceeding those in the overlying water column (Burkhardt and Calci 2000; Rehnstam-Holm and Hernroth 2005; Araud et al. 2016; Amoroso et al. 2020). Because of their ability to accumulate organic and inorganic contaminants, wild bivalve shellfish may be exploited as biological monitors for the surveillance of pollution in coastal environments (Viarengo and Canesi 1991; Donia et al. 2012; Gao et al. 2015; Kim et al. 2016).

The consumption of shellfish harvested from faecally contaminated waters is directly associated with outbreaks of viral gastroenteritis (reviewed in Bellou et al., 2013). Such outbreaks occur on a regular basis worldwide (Le Guyader et al. 2008; Westrell et al. 2010; Iritani et al. 2014; Lunestad et al. 2016; Woods et al. 2016; Meghnath et al. 2019) with potentially significant associated economic costs (Rheingans et al. 2009; Navas et al. 2015; Bartsch et al. 2016; Papadopoulos et al. 2019). Among the enteric viruses, NoV and HAV represent the majority of viral illnesses (Iizuka et al. 2010; Pepe et al. 2012; Fusco et al. 2013, 2019; La Bella et al. 2017), although other viruses like HEV, HAstV, RV, $\mathrm{SaV}$ and $\mathrm{AiV}$ impact shellfisheries with symptoms that are more or less similar to those caused by NoVs (Pina et al. 1998; Le Guyader et al. 2008; Nakagawa-Okamoto et al. 2009; Iritani et al. 2014; La Bella et al. 2017; La Rosa et al. 2018).

To reduce the risk of shellfish-associated infections, sanitary regulations based on bacterial indicators (e.g. Escherichia coli and Salmonella) in shellfish or their growing waters have been instituted in many countries. However, the inadequacy of the bacterial indicators for virus detection makes it necessary to develop new prevention strategies based on viral analysis, for improved regulatory standards (Flannery et al. 2009; Baert et al. 2011). Furthermore, methods to process shellfish post-harvest (e.g. depuration, relaying and heat treatment) are effective at reducing bacterial loading, but their efficacy at reducing viral loading to non-infectious levels may be limited (Baker 2016; Richards 2016). Consequently, improved processing procedures need to be developed to enhance shellfish safety.

\section{Human Enteric Viruses in African Aquatic Environments}

Over one-hundred studies from twelve African countries have reported on the presence of enteric viruses in environmental water samples (Figure 1). These studies were identified using the electronic databases PubMed and Google Scholar and the search words "enteric virus", "rotavirus", "norovirus", "sapovirus", "calicivirus", "astrovirus", "enterovirus", "hepatitis A virus", "aichivirus", "hepatitis E virus", "adenovirus", "bocavirus", "wastewater", "sewage", "effluent", "influent", "drainage water", "drinking water", "ground water", "surface water", "irrigation water", "Africa" and "name of country" in various combinations. Most of the studies were conducted in South Africa (39), Egypt (23) and Tunisia (18), followed by Kenya, Ghana, Morocco and then Uganda with seven, five, five and three studies, respectively. Two studies were conducted each in Tanzania and Nigeria, while only one study was conducted each in Côte d'Ivoire, Benin and Chad. These studies were conducted between 1995 and 2020, and the duration of sampling ranged from

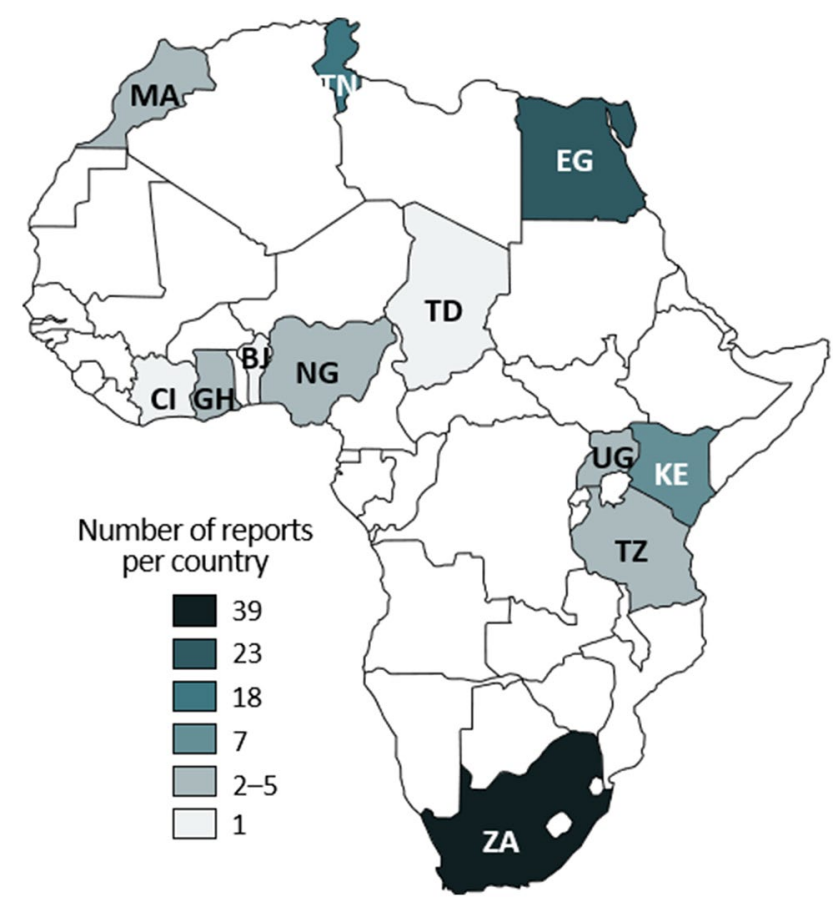

Fig. 1 African countries where enteric viruses have been detected in environmental water samples. Countries are coloured according to the number of studies published. $B J$ Benin, $C I$ Côte d'Ivoire, $E G$ Egypt, $G H$ Ghana, $K E$ Kenya, $M A$ Morocco, $N G$ Nigeria, TD Chad, $T N$ Tunisia, TZ Tanzania, $U G$ Uganda, ZA South Africa 
one month to four years. Collectively, the reports describe the presence, prevalence and diversity of enteric viruses in sewage, wastewater effluent, ground and surface water, and even piped municipal water (reviewed below), indicating the widespread contamination of African water sources with these viral pathogens (Table 1).

\section{Wastewater and Sewage}

A wide range of viruses have been detected in sewage from wastewater treatment plants across Africa. Kiulia et al. (2010) detected HAdV in $87.5-100 \%$ and RVA in $20-100 \%$ of raw sewage samples from two sewage treatment plants in Nairobi, Kenya, while another study detected calicivirus (NoV and $\mathrm{SaV}$ ) RNA in $82 \%$ of raw sewage samples collected from 21 sewage treatment facilities across South Africa (Murray et al. 2013a). More recently, Shaheen et al. (2019a, b) detected AiV RNA and HBoV DNA in 16.6\% and $41.6 \%$ of untreated raw sewage samples collected at the AbuRawash wastewater treatment plant in Giza, while HAdV and RV A were detected in 50\% of urban sewage samples collected from the same site, with concentrations ranging from $10^{3}-10^{8}$ genome copies/litre (GC/L) (Elmahdy et al. 2020). Enteric viruses were also recovered from final wastewater effluents in Egypt (Kamel et al. 2010; Shaheen and Elmahdy 2019; Shaheen et al. 2019a), Ghana (Silverman et al. 2013), Morocco (Amdiouni et al. 2017), South Africa (Olaniran et al. 2012; Osuolale and Okoh 2015; Adefisoye et al. 2016) and Tunisia (Béji-Hamza et al. 2014, 2015; Hassine-Zaafrane et al. 2014; Ouardani et al. 2015; Varela et al. 2018), even after treatment and chlorination. Hamza et al., (2017) detected $\mathrm{HBoV}-1,-2$ and -3 at concentrations of $2.9 \times 10^{3} \mathrm{GC} / \mathrm{L}, 4.1 \times 10^{3} \mathrm{GC} / \mathrm{L}$ and $2.1 \times 10^{3} \mathrm{GC} / \mathrm{L}$ in $34.3 \%, 84.4 \%$ and $87.5 \%$ of treated effluent samples, respectively. These samples were collected from three wastewater treatment plants in Greater Cairo which ultimately discharge treated effluents into the River Nile and Al Manzala Lake (Hamza et al. 2017). A separate study examined the prevalence of $\mathrm{SaV}$ at four Tunisian wastewater treatment plants between 2009 and 2010 and found that treatment did not sufficiently reduce $\mathrm{SaV}$ loads as concentrations of SAV RNA were relatively high in both influent and effluent samples (Varela et al. 2018). These studies highlight the need for improved wastewater treatment methodologies that eliminate enteric viruses from wastewaters prior to discharge into African water environments.

\section{Ground and Surface Water}

There is a significant lack of basic sanitation services and proper wastewater treatment in many African countries (Wang et al. 2014). For example, only 18\%, 26\%, 39\% and $61 \%$ of people living in Algeria, Libya, Morocco and
Egypt, respectively, have access to safely managed sanitation facilities (WHO et al. 2019), while in sub-Saharan Africa, approximately 709 million people are without basic sanitation services, sewer systems or wastewater treatment facilities (UN Habitat 2013; Ezeh et al. 2017; WHO et al. 2019). Consequently, millions of people resort to open defecation, or the use of pit latrines and septic tanks (WHO et al. 2019), which are recognised as major sources of microbial contamination in surrounding water resources within the region (Graham and Polizzotto 2013; Njuguna 2016; Lapworth et al. 2017). Indeed, many studies have described the detection of enteric viruses in contaminated water sources in Africa. For example, studies in Chad (Guerrero-Latorre et al. 2011), Ghana (Gibson et al. 2011; Lutterodt et al. 2018) Kenya (Kiulia et al. 2014), Nigeria (Muhammad et al. 2020), South Africa (Ehlers et al. 2005; Murray and Taylor 2015) and Uganda (Katukiza et al. 2013a, 2013b; Sadik 2016) have reported the contamination of groundwater sources such as boreholes, springs and wells with enteric viruses including EV, HAdV, NoV, SaV and RV.

Untreated or partially treated sewage effluent is a major contaminant of surface water sources in many African cities (Omosa et al. 2012; Adewumi and Oguntuase 2016; Herbig 2019; Okubo et al. 2019), and enteric viruses including EV, HAdV, HAV, HBoV and RV are frequently detected in African rivers, dams and lakes at high concentrations ranging from $1.3 \times 10^{1}-1.5 \times 10^{7} \mathrm{GC} / \mathrm{L}$ (Hamza et al. 2009; Chigor and Okoh 2012a; Katukiza et al. 2013b; Sibanda and Okoh 2013; Shaheen et al. 2019b). The Nile is the main source of water for irrigation and domestic use in Egypt, however, many studies have found this river to be polluted with enteric viruses (El-Senousy et al. 2013a, 2014, 2015; Shaheen et al. 2019b). For example, 4\%, $25 \%, 16.6 \%, 8.3 \%$ and $12.5 \%$ of water samples collected from the Rosetta branch of the Nile in 2017 and 2018 were contaminated with AiV, AstV, NoV, RV and HBoV, respectively (Shaheen et al. 2018, 2019a; Shaheen and Elmahdy 2019), while more recently, Rizk and Allayeh, (2020) detected RVA RNA in $18.75 \%$ of Nile water samples collected in Giza. Similarly, enteric viruses have been found in major surface waters in Kenya, Chad, Nigeria and Uganda (Kiulia et al. 2010, 2014; Guerrero-Latorre et al. 2011; Katukiza et al. 2013a, 2013b; Baker et al. 2018; Bauza et al. 2019; van Zyl et al. 2019; Muhammad et al. 2020). For example, two separate studies detected EV and HAdV in water samples from Homa Bay, Lake Victoria (Sadik 2016; Opere 2019). Over the last 25 years, many studies have revealed the presence of enteric viruses in South African rivers and dams, which are essential water sources for the surrounding communities (Taylor et al. 2001; Sibanda and Okoh 2012; Sibanda et al. 2013; Saïd et al. 2014; Lin et al. 2015; Potgieter et al. 2020). For example, several studies have identified HAdV, HAV and 


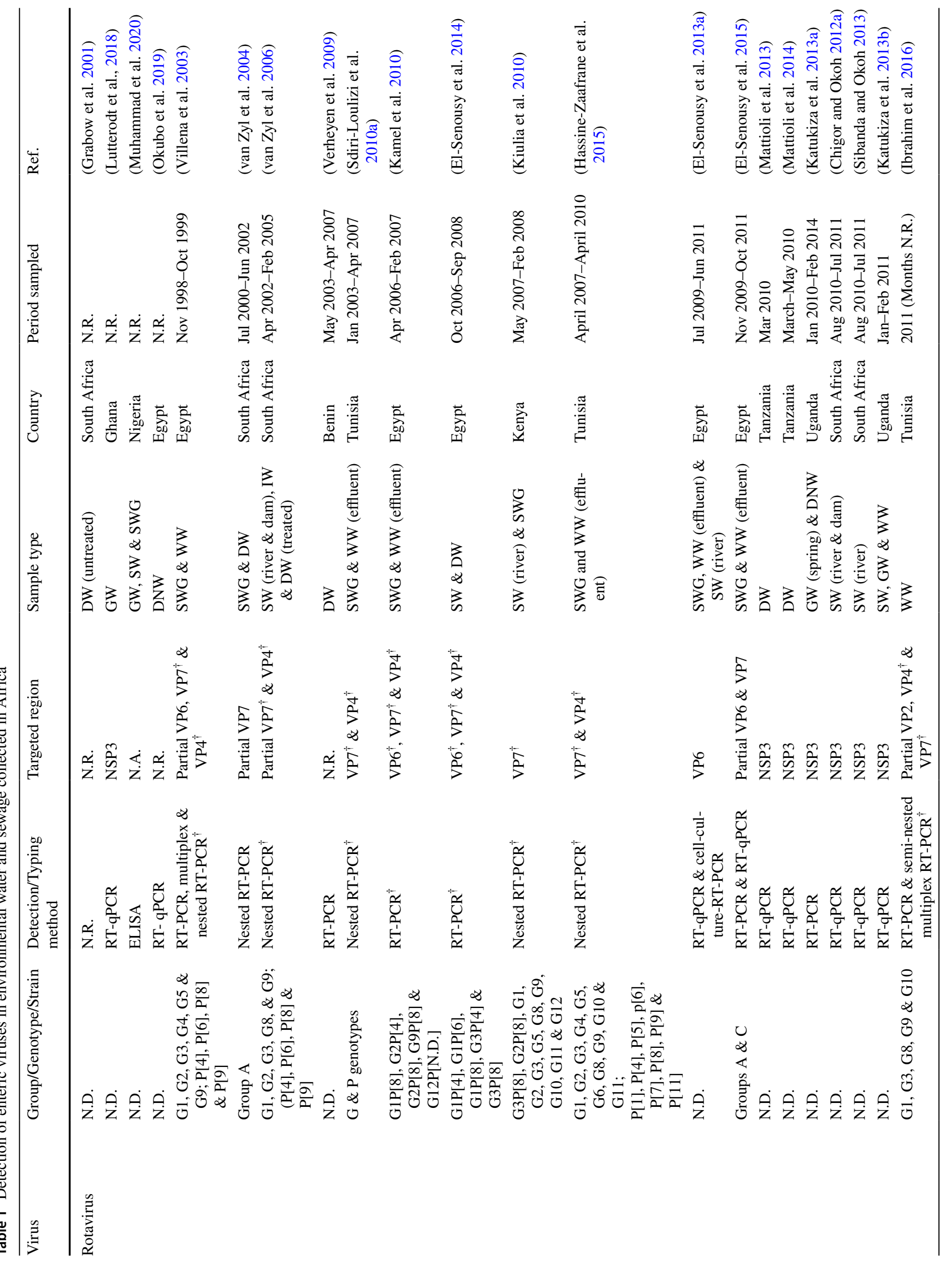




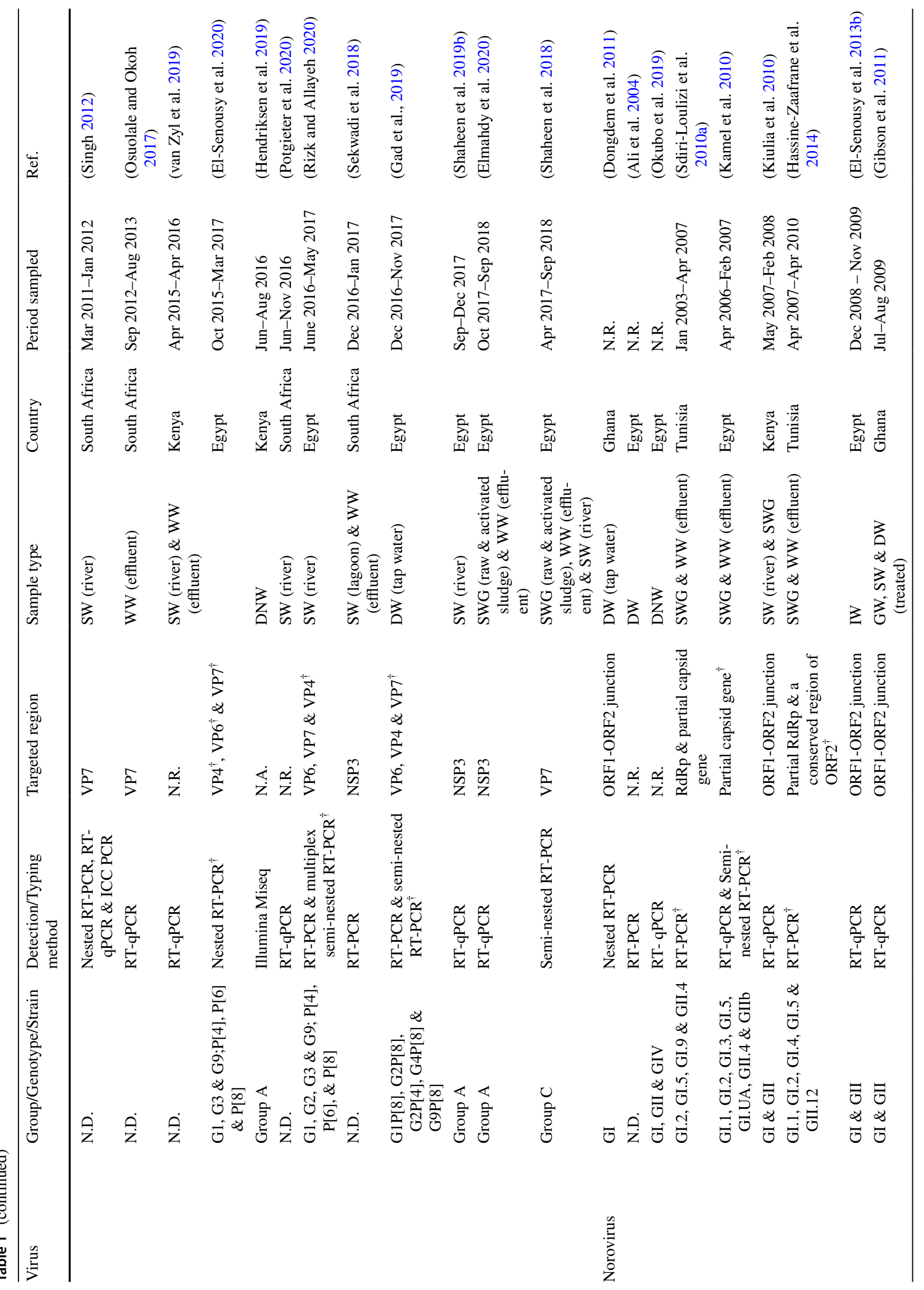




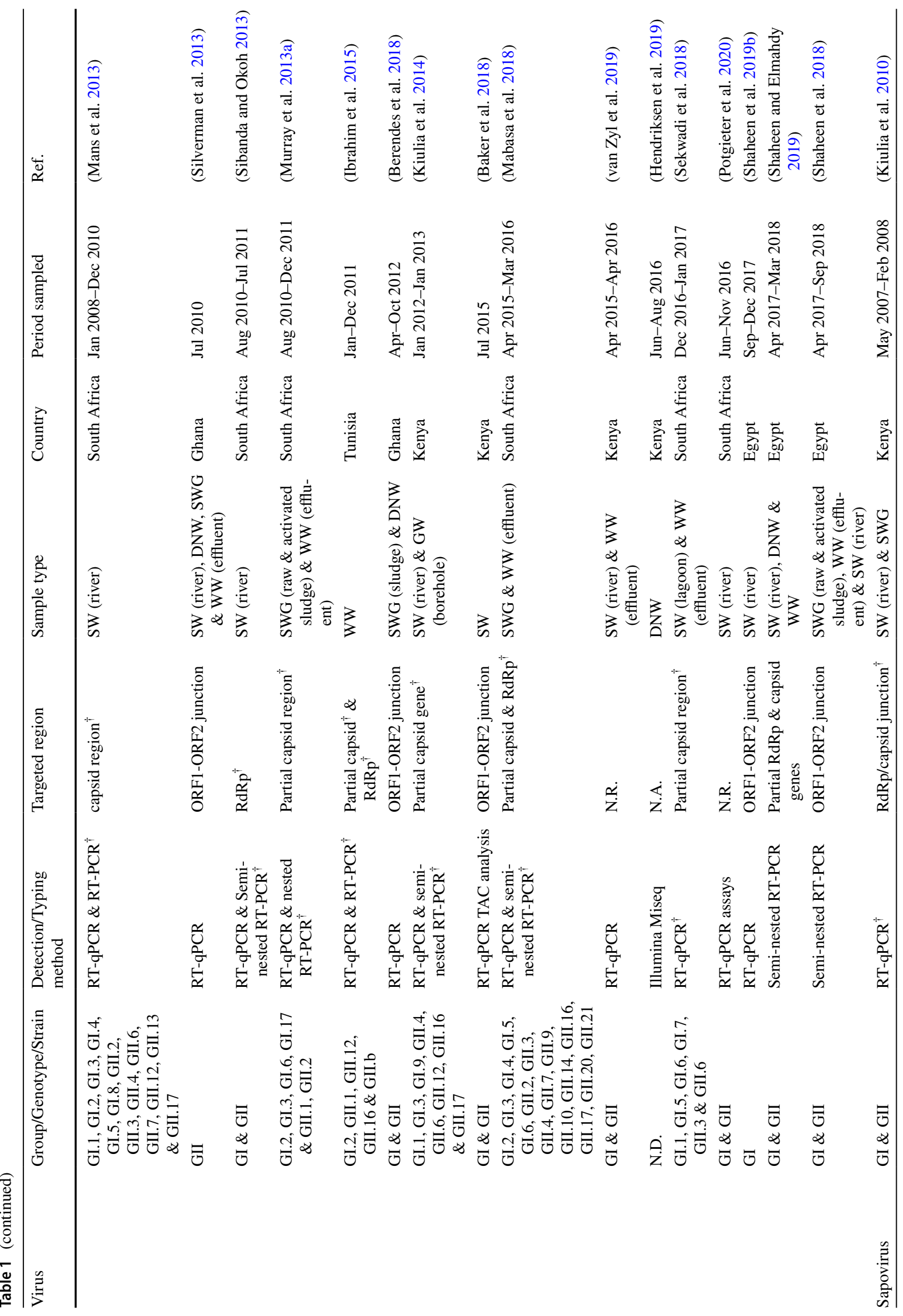




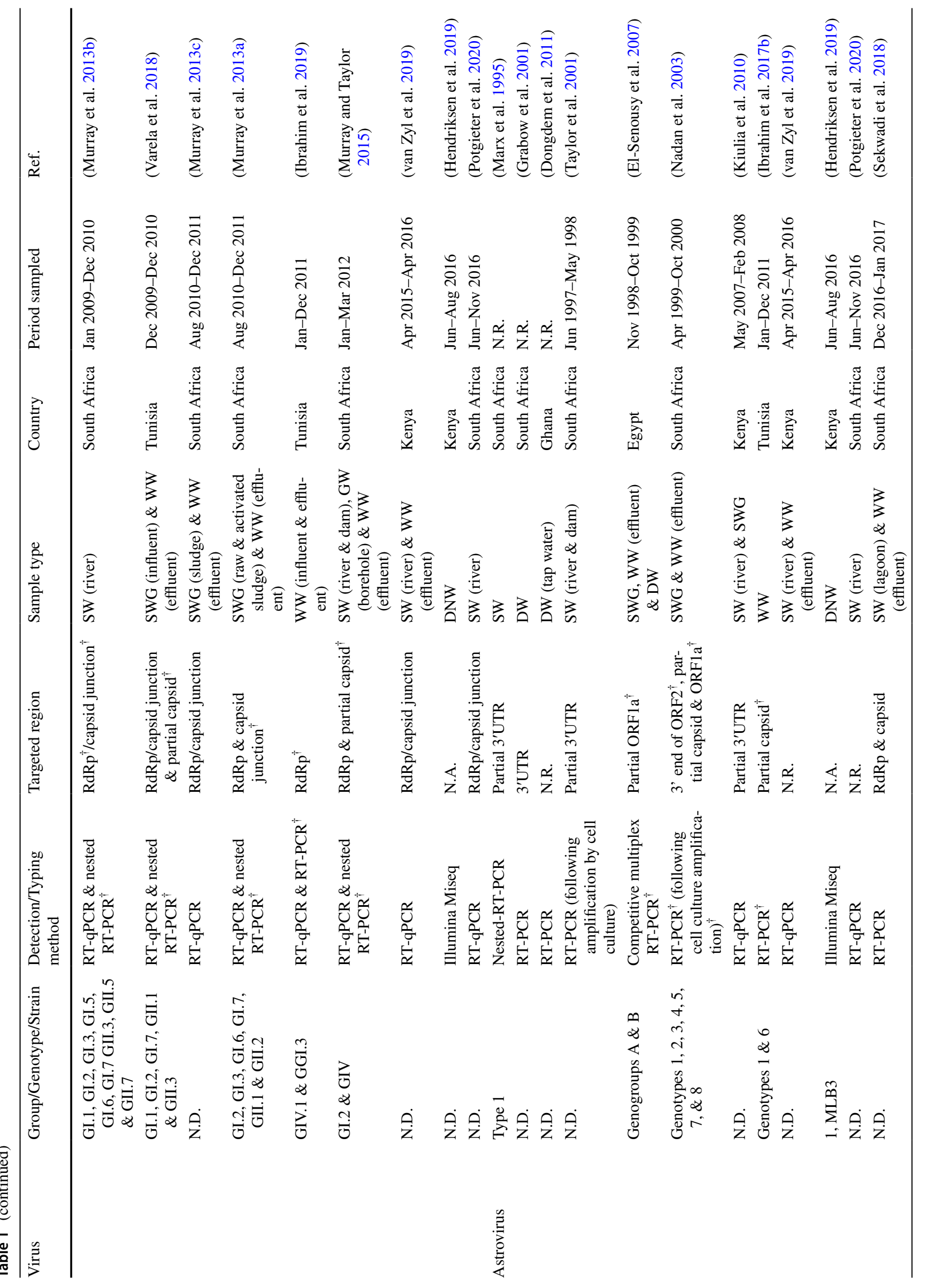




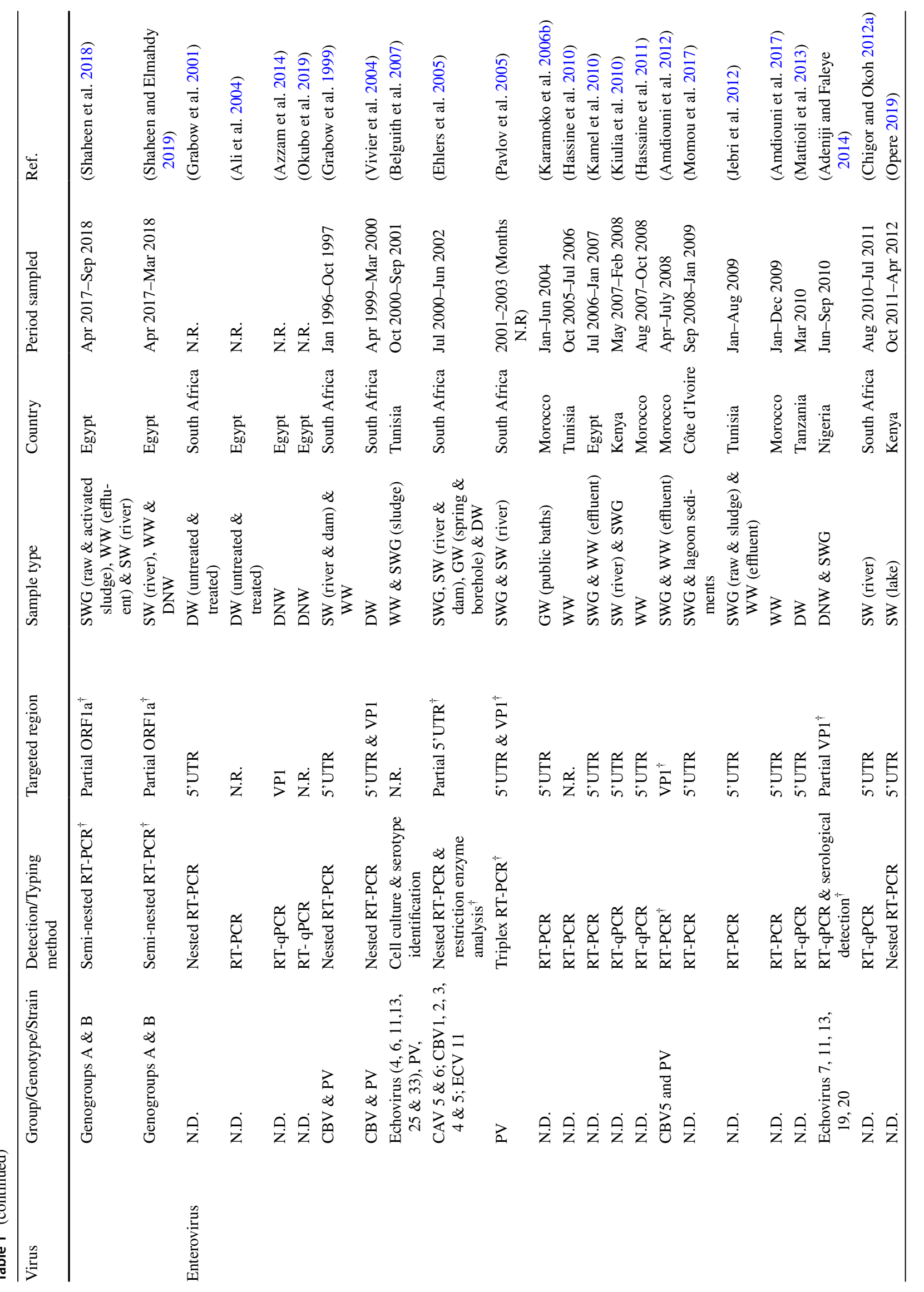




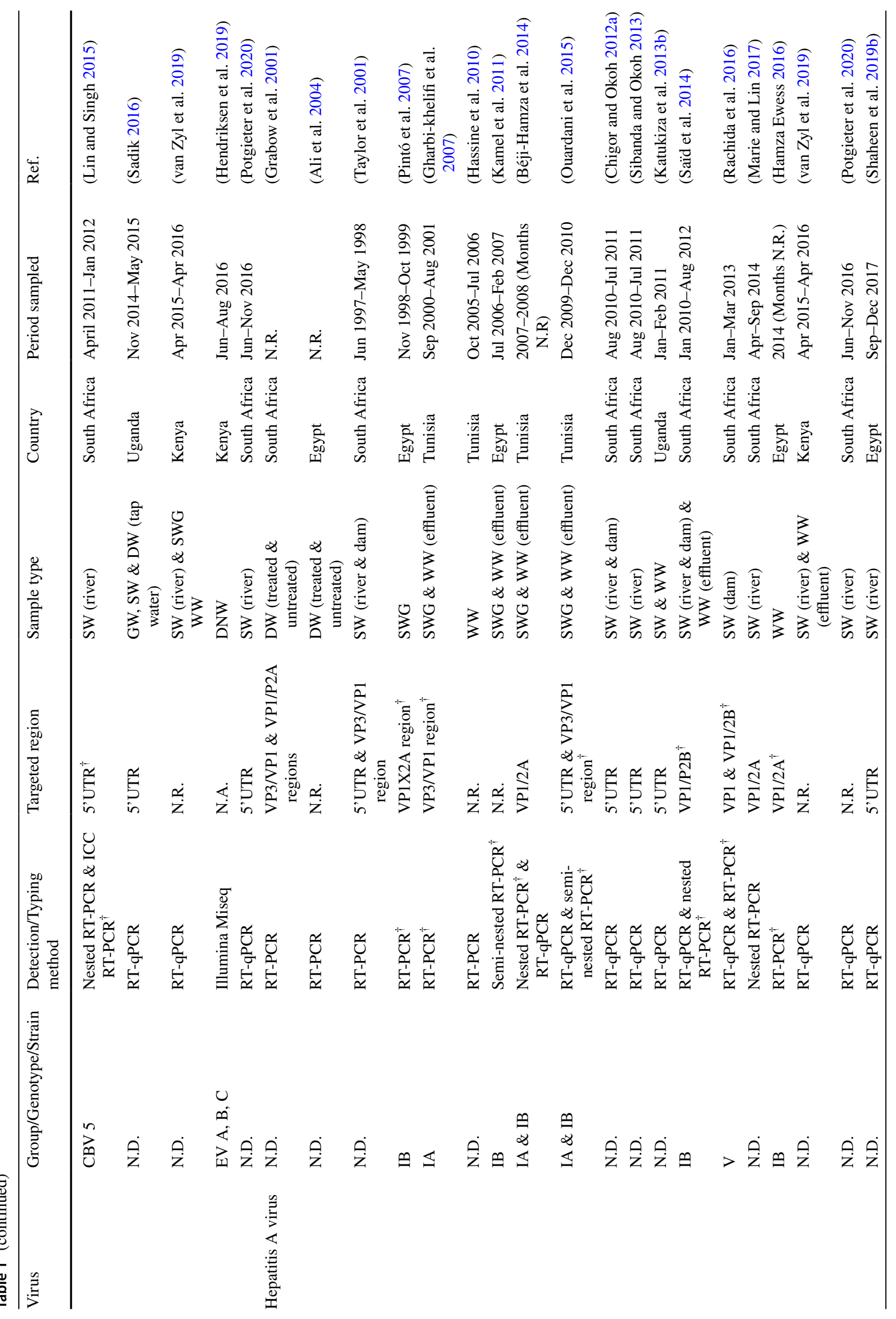




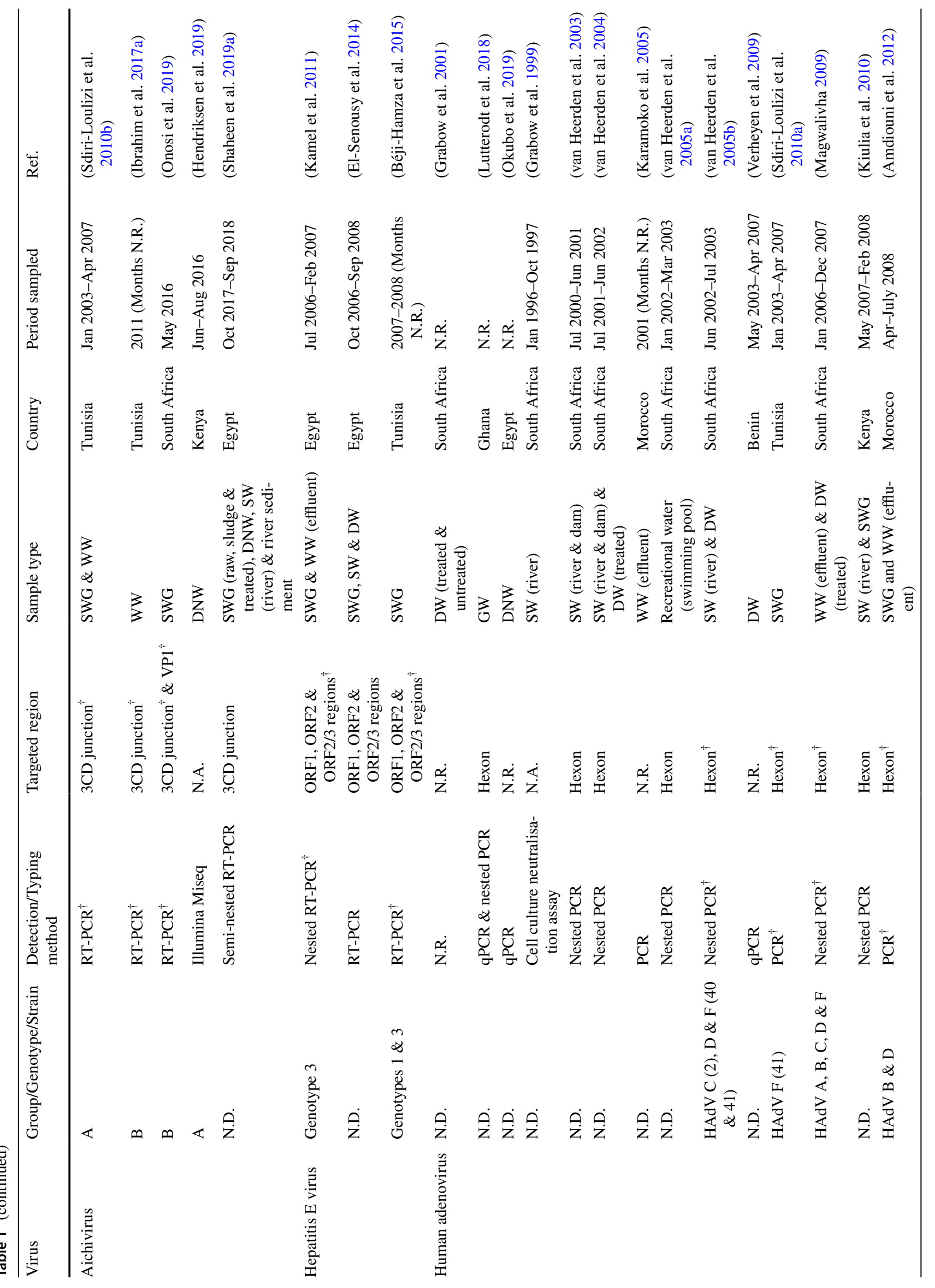




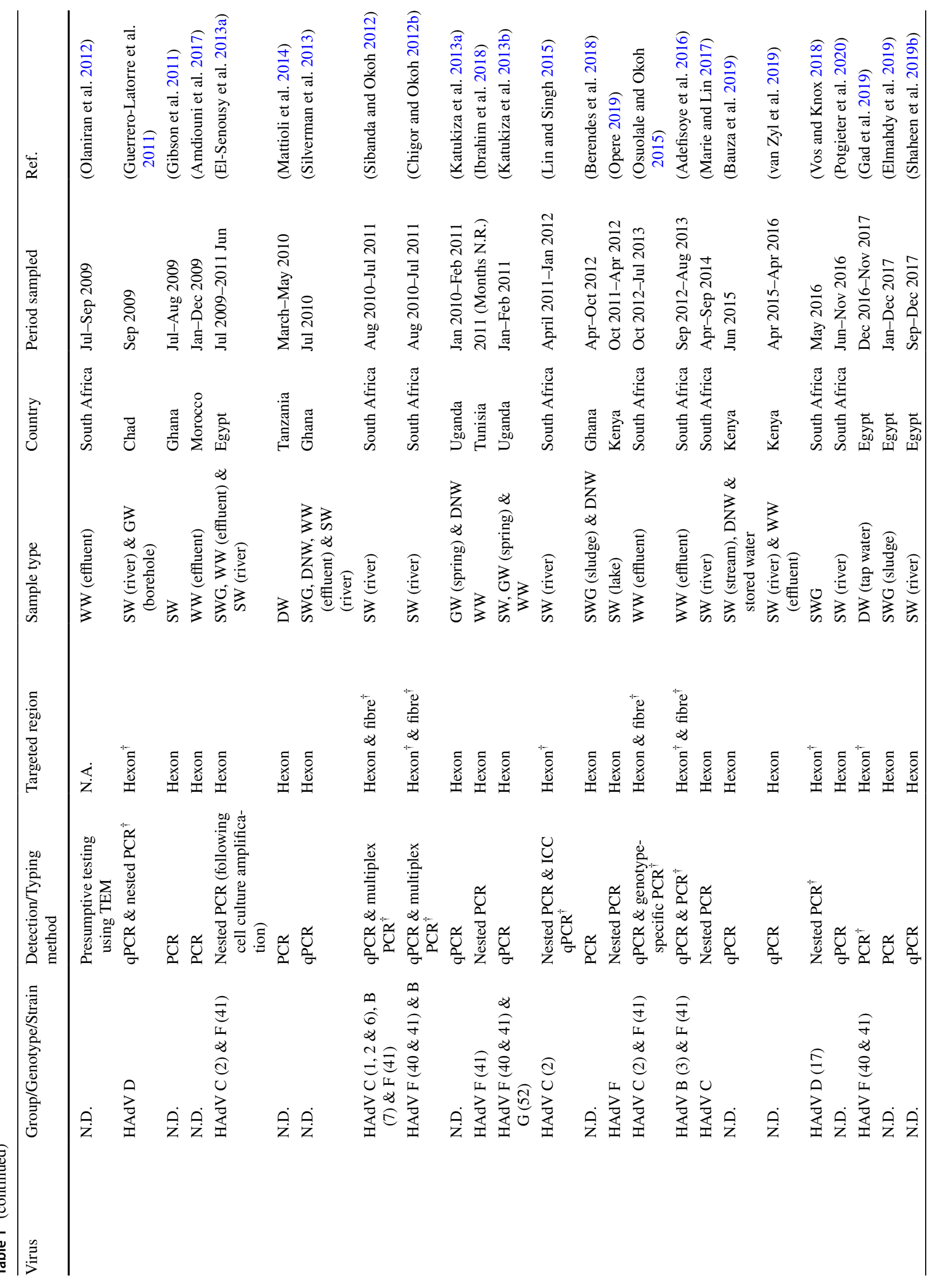




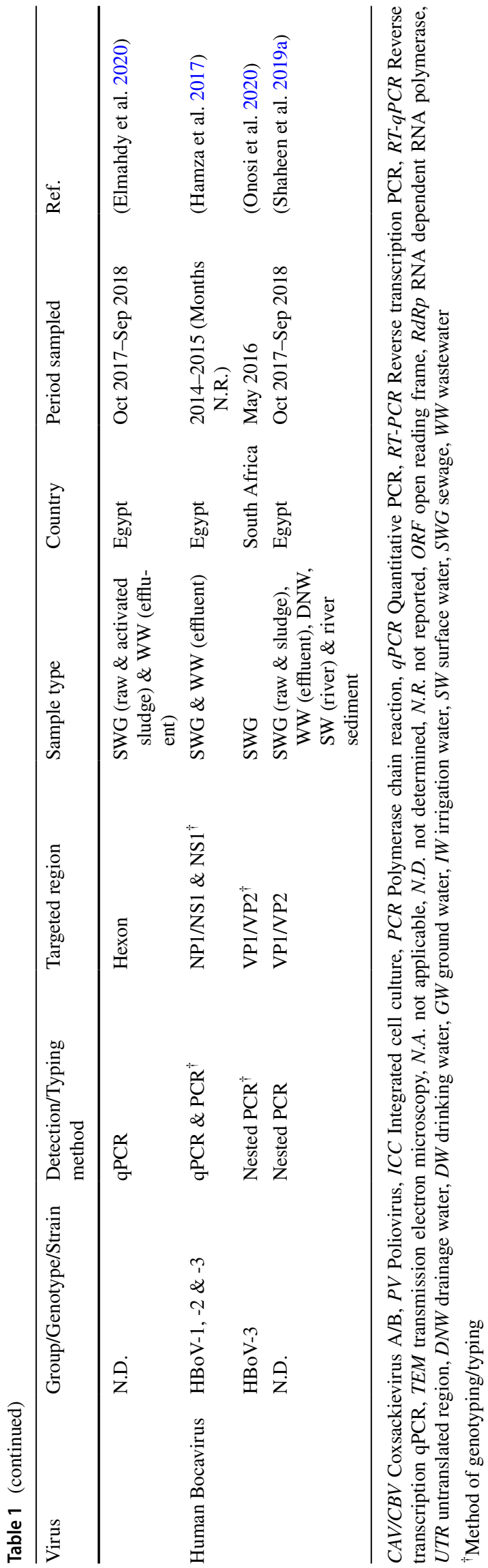

in some cases EV, NoV and RV in water samples from the Tyume and Buffalo rivers of the Eastern Cape (Chigor and Okoh 2012a, 2012b; Sibanda and Okoh 2012, 2013), the Klip River and Vaal dam in the Gauteng province (Taylor et al. 2001), and the Umhlangane river in KwaZulu-Natal (Marie and Lin 2017). From 2008 to 2010, Mans et al. (2013) reported the presence of NoV RNA in 66\%, 95\% and $21 \%$ of water samples from the Klip, Rietspruit and Suikerbosrant rivers, respectively. During this period, SaV RNA was detected in $39-54 \%, 83-92 \%$ and $14-20 \%$ of water samples from the same rivers (Murray et al. 2013b). More recently, HAdV, NoV GI and GII together with EV, HAV, HAstV, HAdV and SaV were detected in water samples from the Madadzhe river in the Limpopo province, which is exploited for domestic and agricultural activities (Potgieter et al. 2020).

The widespread contamination of African rivers, canals, dams and lakes with viral pathogens constitutes a significant health risk to the millions of people who depend on these surface waters for drinking, irrigational, domestic and recreational activities (Chigor et al. 2014; Sibanda et al. 2015; Pichel et al. 2019; UNESCO 2019). From 2002 to 2004 van Zyl et al. (2006) detected RV A in 14\% of irrigation water samples and $1.7 \%$ of corresponding raw vegetable samples collected in the Western Cape, Gauteng and Limpopo provinces of South Africa. In Egypt, marginal water from drainage canals, often contaminated with enteric pathogens, is unofficially used for the irrigation of crops, despite the increased risk of viral contamination of agricultural products. El-Senousy et al. (2013b) detected NoV RNA in 31.9\% of irrigation water samples from the Daqahlia governorate in 2008 and 2009, while more recently, Okubo et al. (2019) identified AiV, EV, HAdV, HAV, HEV, NoVs (GI, GII and GIV) and RV in $100 \%$ of irrigation water samples from the Umoum agricultural drainage canal, and its tributaries. Enteric viruses have even been identified in treated drinking water produced at several treatment facilities across Africa (Ali et al. 2004; Ehlers et al. 2005; van Zyl et al. 2006; ElSenousy et al. 2014). In South Africa, Grabow et al. (2001) recovered viable EV, HAdV and HAV in $23 \%$ of chlorinated drinking water samples, while van Heerden and colleagues detected HAdV in $29.8 \%$ and $5.32 \%$ of drinking water samples between 2001-2002 and 2002-2003, respectively (van Heerden et al. 2004, 2005b). Similar studies have reported the presence of EV, HAV, HEV, HAstV, NoV and RV in chlorinated drinking water in Egypt (Ali et al. 2004; El-Senousy et al. 2007, 2014; Rizk and Allayeh 2018). Recently, Gad et al. (2019) detected HAdV DNA in 8.9\%, and RV RNA in $15.6 \%$ of tap water samples from five Egyptian cities including Cairo and Giza. Furthermore, treated tap and kiosk water in Uganda and Ghana have been found to be contaminated with enteric viruses including EV and NoV (GII), respectively (Gibson et al. 2011; Sadik 2016). 


\section{Enteric viruses in African shellfish}

Over the past two decades, only seventeen studies detecting human enteric viruses in African shellfish have been reported (Figure 2 and Table 2). These studies were identified by searching the PubMed and Google Scholar databases for studies which included terms such as "enteric virus", "rotavirus", "norovirus", "sapovirus", "calicivirus", "astrovirus", "enterovirus", "hepatitis A virus", "aichivirus", "hepatitis E virus", "adenovirus", "bocavirus", "shellfish", "mussel", "cockle", "periwinkle", "oyster" "Africa" and the names of African countries. The first report was published by Karamoko et al. (2005), who detected HAdV in $20 \%$ of mussel samples grown in Casablanca, Morocco (Karamoko et al. 2005). Subsequently, two additional studies reported the presence of HAdV in African shellfish; Vos and Knox (2018) detected HAdV D17 in mussels collected from the Swartkops river estuary in Port Elizabeth, South Africa, while Benabbes et al. (2013a) identified HAdV and EV in $52.3 \%$ and $36.3 \%$ of Moroccan shellfish samples (clams and cockles), respectively. Collectively, several other studies have detected NoV (GI and GII), SaV, EV and HAV in cockles, clams and oysters harvested from different growing waters in Morocco (Karamoko et al. 2006a; Benabbes et al. 2013b; El Moqri et al. 2019). Polo et al. (2010) detected

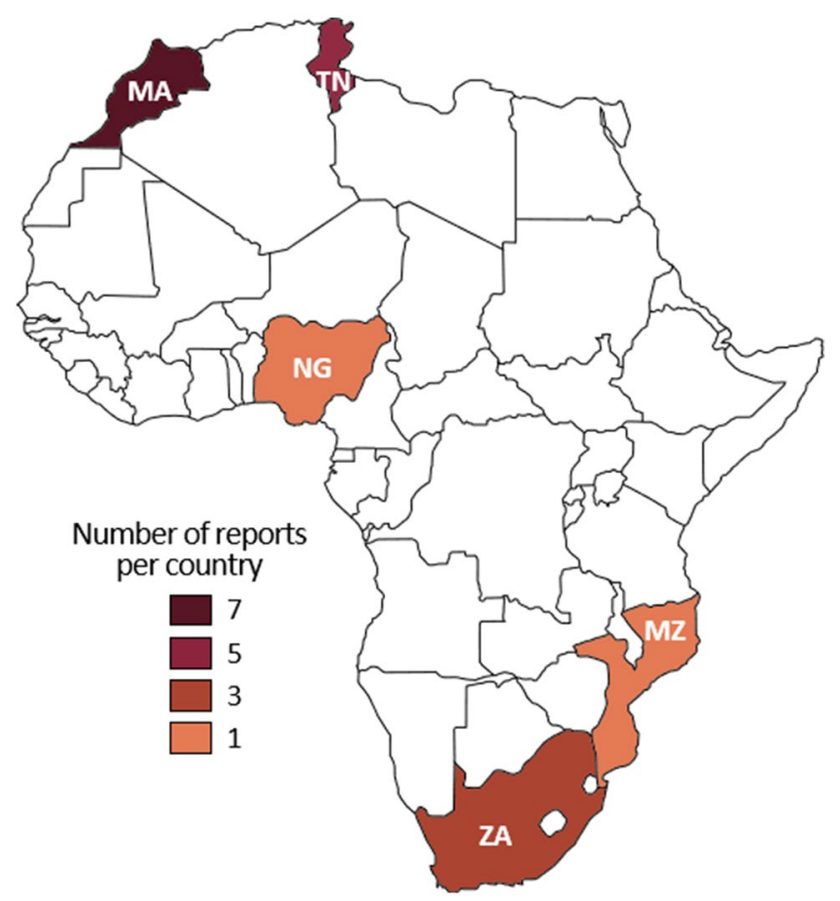

Fig. 2 African countries where enteric viruses have been detected in shellfish. Countries are coloured according to the number of studies published. $M A$ Morocco, $M Z$ Mozambique, $N G$ Nigeria, $T N$ Tunisia, ZA South Africa
NoV (GI and GII) in $15 \%$ and HAV in $6 \%$ of Moroccan shellfish at high concentrations, ranging from $4.7 \times 10^{3}$ to $7.7 \times 10^{7} \mathrm{GC} / \mathrm{g}$ digestive tissue. Similarly, enteric viruses have been detected in bivalve molluscs grown along the Tunisian coastline (Gharbi-khelifi et al. 2007; Zormati et al. 2018). Elamri (2006) detected HAstV in 61\%, NoV in 35\%, $\mathrm{HAV}$ in $26 \%$ and $\mathrm{EV}$ in $4.3 \%$ (one mussel) of shellfish (mussels and clams) collected from Tunisian waters from July 2000 to September 2001. In two separate studies, $1.6 \%$ and $6.6 \%$ of shellfish collected from a fishing zone located near a wastewater outlet site in Monastir, Tunisia, tested positive for NoV (GI.2) and AiV A, respectively (Sdiri-Loulizi et al. 2010a, 2010b). Furthermore, Onosi et al (2019) reported the presence of AiV B in mussels collected from the Swartkops river estuary in Port Elizabeth, South Africa. In another study, the authors detected HBoV-2 in the same mussel samples, making it the first report of $\mathrm{HBoV}$ in shellfish from Africa (Onosi et al. 2020). Finally, there are only single reports of enteric viruses in shellfish from Mozambique (Nenonen et al. 2006) and Nigeria (Babalola et al. 2019), where HAV IB and NoV were detected in clams and periwinkles, respectively.

To date, there are only a few reports of shellfish-associated gastroenteritis from Africa (Potasman et al. 2002; Bellou et al. 2013); however, the aforementioned studies highlight the risk of transmission and disease outbreak through the consumption of virus-contaminated shellfish grown in African waters. The presence of viral pathogens in edible molluscs is a health risk not only for local populations but also for people in countries where such foods are imported. For example, Moroccan molluscs exported to Spain were previously found to be contaminated with NoV and HAstV (Polo et al. 2010), while recent outbreaks of gastroenteritis in North America, Australia and Europe were attributed to the consumption of food products imported from Egypt (Aboubakr and Goyal 2019). Collectively, these reports highlight the need for efficient surveillance programmes and epidemiological studies to fully understand the burden of virus-contaminated shellfish on public health and economies in Africa.

\section{Conclusions and future perspectives}

Enteric viruses remain a serious public health threat globally, posing an enormous burden on the economies of many countries. This is particularly true of the developing world where most of the population tend to inhabit urban informal settlements or rural areas, and where the predominant mode of transmission is linked to sewage-contaminated water. This review testifies to the extent of the problem on the African continent by reviewing over 100 investigations conducted in 13 African countries in which the occurrence 
Table 2 Detection of enteric viruses in shellfish collected in Africa

\begin{tabular}{|c|c|c|c|c|c|c|c|}
\hline Virus & $\begin{array}{l}\text { Group/Genotype/ } \\
\text { Strain }\end{array}$ & $\begin{array}{l}\text { Detection/Typing } \\
\text { method }\end{array}$ & Targeted region & Sample Type & Country & Period sampled & Ref. \\
\hline \multirow[t]{7}{*}{ Norovirus } & N.D. & RT-PCR & Partial RdRp & Clams \& mussels & Tunisia & $\begin{array}{l}\text { Jul 2000-Sep } \\
2001\end{array}$ & (Elamri et al. 2006) \\
\hline & GI.2 & RT-PCR $^{\dagger}$ & $\begin{array}{l}\text { Partial RdRp }{ }^{\dagger} \& \\
\text { capsid genes }\end{array}$ & Clam & Tunisia & $\begin{array}{l}\text { Jan 2003-Apr } \\
2007\end{array}$ & $\begin{array}{l}\text { (Sdiri-Loulizi et al. } \\
\text { 2010a) }\end{array}$ \\
\hline & GI \& GII & RT-qPCR & $\begin{array}{l}\text { ORF1-ORF2 } \\
\text { junction }\end{array}$ & Clams & Morocco & $\begin{array}{l}\text { Sep 2006-Mar } \\
2009\end{array}$ & (Polo et al. 2010) \\
\hline & GI \& GII & RT-qPCR & $\begin{array}{l}\text { ORF1-ORF2 } \\
\text { junction }\end{array}$ & $\begin{array}{l}\text { Clams, cockles \& } \\
\text { oysters }\end{array}$ & Morocco & $\begin{array}{l}\text { Oct 2006-Aug } \\
2010\end{array}$ & $\begin{array}{l}\text { (Benabbes et al. } \\
\text { 2013b) }\end{array}$ \\
\hline & GI \& GII & RT-qPCR & N.R. & Clams & Tunisia & $\begin{array}{l}\text { Mar 2013-Dec } \\
2016\end{array}$ & $\begin{array}{l}\text { (Zormati et al. } \\
\text { 2018) }\end{array}$ \\
\hline & GI \& GII & RT-qPCR & $\begin{array}{l}\text { ORF1-ORF2 } \\
\text { junction }\end{array}$ & Clams \& oysters & Morocco & $\begin{array}{l}\text { Nov 2015-Feb } \\
2017\end{array}$ & $\begin{array}{l}\text { (El Moqri et al. } \\
\text { 2019) }\end{array}$ \\
\hline & N.D. & $\begin{array}{l}\text { Norovirus Combo } \\
\text { Card Test } \\
\left.\text { (CerTest }^{\circledR}\right)\end{array}$ & N.A. & Periwinkles & Nigeria & $\begin{array}{l}\text { Oct 2018-Mar } \\
2019\end{array}$ & $\begin{array}{l}\text { (Babalola et al. } \\
\text { 2019) }\end{array}$ \\
\hline Sapovirus & N.D. & RT-qPCR & Partial RdRp & $\begin{array}{l}\text { Clams, cockles \& } \\
\text { oysters }\end{array}$ & Morocco & $\begin{array}{l}\text { Oct 2006-Aug } \\
2010\end{array}$ & $\begin{array}{l}\text { (Benabbes et al. } \\
\text { 2013b) }\end{array}$ \\
\hline \multirow[t]{2}{*}{ Astrovirus } & N.D. & RT-PCR & 3'UTR & Clams \& mussels & Tunisia & $\begin{array}{l}\text { Jul 2000-Sep } \\
2001\end{array}$ & (Elamri et al. 2006) \\
\hline & N.D. & RT-PCR & N.R. & Clams & Morocco & $\begin{array}{l}\text { Sep 2006-Mar } \\
2009\end{array}$ & (Polo et al. 2010) \\
\hline \multirow[t]{5}{*}{ Enterovirus } & N.D. & RT-PCR & 5 'UTR & Mussels & Morocco & N.R. & $\begin{array}{l}\text { (Karamoko et al. } \\
\text { 2006a) }\end{array}$ \\
\hline & N.D. & RT-PCR & 5'UTR & Mussels & Tunisia & $\begin{array}{l}\text { Jul 2000-Sep } \\
2001\end{array}$ & (Elamri et al. 2006) \\
\hline & N.D. & RT-PCR & 5 'UTR & Cockles \& clams & Morocco & $\begin{array}{l}\text { Oct 2006-Apr } \\
2008\end{array}$ & $\begin{array}{l}\text { (Benabbes et al. } \\
\text { 2013a) }\end{array}$ \\
\hline & N.D. & RT-qPCR & 5 'UTR & Cockles \& oysters & Morocco & $\begin{array}{l}\text { Oct 2006-Aug } \\
2010\end{array}$ & $\begin{array}{l}\text { (Benabbes et al. } \\
\text { 2013b) }\end{array}$ \\
\hline & Sabin 1 \& NPEVs & $\begin{array}{l}\text { RT-qPCR (follow- } \\
\text { ing cell culture } \\
\text { amplification) }\end{array}$ & N.R. & Mussels & Morocco & $\begin{array}{l}\text { Feb 2014-Feb } \\
\quad 2015\end{array}$ & $\begin{array}{l}\text { (Azzouzi et al. } \\
\text { 2017) }\end{array}$ \\
\hline \multirow[t]{5}{*}{ Hepatovirus } & IA & RT-PCR ${ }^{\dagger}$ & VP3/VP1 region ${ }^{\dagger}$ & Carpet shells & Tunisia & $\begin{array}{l}\text { Sep 2000-Aug } \\
2001\end{array}$ & $\begin{array}{l}\text { (Gharbi-khelifi } \\
\text { et al. 2007) }\end{array}$ \\
\hline & IB & Nested RT-PCR ${ }^{\dagger}$ & $\begin{array}{l}\text { 5'UTR, VP3/VP1 } \\
\text { \& VP1/P2A } \\
\text { regions }^{\dagger}\end{array}$ & Clams & Mozambique & Mar-Nov 2004 & $\begin{array}{l}\text { (Nenonen et al. } \\
\text { 2006) }\end{array}$ \\
\hline & N.D. & RT-qPCR & 5'UTR & Cockles \& oysters & Morocco & $\begin{array}{l}\text { Oct 2006-Aug } \\
2010\end{array}$ & $\begin{array}{l}\text { (Benabbes et al. } \\
\text { 2013b) }\end{array}$ \\
\hline & N.D. & RT-qPCR & N.R. & Clams & Tunisia & $\begin{array}{l}\text { Mar 2013-Dec } \\
2016\end{array}$ & $\begin{array}{l}\text { (Zormati et al. } \\
\text { 2018) }\end{array}$ \\
\hline & N.D. & RT-PCR & 5 'UTR & Clams \& mussels & Tunisia & $\begin{array}{l}\text { Jul 2000-Sep } \\
2001\end{array}$ & (Elamri et al. 2006) \\
\hline \multirow[t]{2}{*}{ Aichivirus } & $\mathrm{A}$ & $\mathrm{RT}-\mathrm{PCR}^{\dagger}$ & $3 \mathrm{CD}$ junction ${ }^{\dagger}$ & $\begin{array}{l}\text { Shellfish (type } \\
\text { N.R.) }\end{array}$ & Tunisia & $\begin{array}{l}\text { Jan 2003-Apr } \\
2007\end{array}$ & $\begin{array}{l}\text { (Sdiri-Loulizi et al. } \\
\text { 2010b) }\end{array}$ \\
\hline & B & $\mathrm{RT}^{-\mathrm{PCR}^{\dagger}}$ & $3 \mathrm{CD}$ junction ${ }^{\dagger}$ & Mussels & South Africa & May 2016 & (Onosi et al. 2019) \\
\hline \multirow[t]{3}{*}{$\begin{array}{l}\text { Human Adeno- } \\
\text { virus }\end{array}$} & N.D. & PCR & N.R. & Mussels & Morocco & $\begin{array}{l}2001 \text { (Months } \\
\text { N.R.) }\end{array}$ & $\begin{array}{l}\text { (Karamoko et al. } \\
2005)\end{array}$ \\
\hline & N.D. & PCR & Hexon & Clams \& cockles & Morocco & $\begin{array}{l}\text { Oct 2006-Apr } \\
2008\end{array}$ & $\begin{array}{l}\text { (Benabbes et al. } \\
\text { 2013a) }\end{array}$ \\
\hline & HAdV D (17) & Nested $\mathrm{PCR}^{\dagger}$ & Hexon $^{\dagger}$ & Mussels & South Africa & May 2016 & $\begin{array}{l}\text { (Vos and Knox } \\
\text { 2018) }\end{array}$ \\
\hline Human Bocavirus & HBoV-2 & Nested $\mathrm{PCR}^{\dagger}$ & VP1/VP2 region ${ }^{\dagger}$ & Mussels & South Africa & May 2016 & (Onosi et al. 2020) \\
\hline
\end{tabular}

NPEV non-polio enterovirus, $N . D$. not determined, $N . R$. not reported, $O R F$ open reading frame, $R d R p$ RNA dependent RNA polymerase, $U T R$ untranslated region

${ }^{\dagger}$ Method of genotyping/typing 
of enteric viruses was described in a wide range of samples including not only raw sewage but also groundwater, open water sources, bivalve shellfish and, alarmingly, drinking water. While many of these studies are limited to simple molecular detection of specific viruses in selected samples a few go further to describe the quantification, prevalence and links to disease outbreaks (see for example: El-Senousy et al. 2015, 2020; Elmahdy et al. 2019; Okubo et al. 2019). When assessing the public health risks posed by enteric viruses in the environment, it must be acknowledged that standard molecular-based detection methods cannot discriminate between infectious viruses and non-viable virus particles and that additional data is needed for accurate risk estimates (Rodríguez et al. 2009; Leifels et al. 2016). The first step in attempting to alleviate the burden of disease will be to further understand the true prevalence, molecular epidemiology, viability and circulation of enteric viruses by conducting systematic surveillance studies and evaluating the virological safety of water and food prior to consumption or utilisation for daily living purposes. Recently, sewage epidemiology or wastewater-based epidemiology (WBE) has been successfully used as a surveillance and non-invasive early warning approach for outbreaks of pathogenic enteric viruses such as poliovirus, HAV and NoV (Asghar et al. 2014; Hellmér et al. 2014). In light of the current COVID19 pandemic, research groups worldwide are evaluating this tool as a way to predict future coronavirus outbreaks (Ahmed et al. 2020a; Bivins et al. 2020; Haramoto et al. 2020; Kumar et al. 2020; La Rosa et al. 2020; Medema et al. 2020; Nemudryi et al. 2020; Wu et al. 2020). Along with clinical testing, WBE may represent a viable means of largescale population-wide surveillance of imminent infectious disease outbreaks, particularly in resource poor regions in African nations. Additionally, Quantitative Microbial Risk Assessment (QMRA) could be used to estimate population health risks posed by these waterborne pathogens and inform water management strategies (Howard et al. 2006; Owens et al. 2020). Although QMRA has been widely used in developed countries (Bichai and Smeets 2013; Owens et al. 2020), less-developed countries such as those in Africa, with limited data and resources, have greater challenges when applying this technique (Howard et al. 2006; Chigor et al. 2014; Van Abel and Taylor 2018). A recent review of QMRA in sub-Saharan Africa (Van Abel and Taylor 2018) outlined these challenges such as the lack of quantification data and defined several steps including the collection of further data on virus detection, concentration and infectivity, to improve this methodology within the region.

The fact that reports of enteric viruses in water environments to date are limited to only one quarter of Africa's 54 countries highlights the need for further investigations to better understand the occurrence of these pathogens and their associated public health risk on the continent.
Moreover, because wastewater treatment systems in African countries tend to be either non-existent or poorly managed, the threat of human exposure to enteric viruses will remain. There is thus an urgent need for all stakeholders including governments, the private sectors and the public to invest heavily in basic sanitation services as well as the development of innovative wastewater treatment strategies to reduce faecal contamination of vital water sources utilised for irrigation, drinking, food-processing and domestic or recreational activities.

Acknowledgements This work was supported by a Research Council (RC, Rhodes University) grant.

Authors Contributions Conceptualisation: $\mathrm{CK}$ and NU; Literature search: NU and GL; Compilation of tables and figures: NU; Writing of manuscript and editing: All authors.

\section{Compliance with ethical standards}

Conflict of interest The authors declare no conflict of interest.

\section{References}

Abdel-Daim, S. E., Shaheen, M. N. F., Hosseney, E. N., Elhosainy, A. M., Nehal, I. A., Elmahdy, M. E., \& Ali, M. A. (2019). Molecular Detection and Genotyping of Group A Rotavirus by Multiplex Semi-Nested RT-PCR in Sewage Water and Sludge. Open Access Journal of Microbiology \& Biotechnology, 4(1), 1-8. https://doi. org/https://doi.org/10.23880/oajmb-16000141

Aboubakr, H., \& Goyal, S. (2019). Involvement of Egyptian foods in foodborne viral illnesses: The burden on public health and related environmental risk factors: An overview. Food and Environmental Virology, 11(4), 315-339. https://doi.org/10.1007/ s12560-019-09406-z.

Adefisoye, M. A., Nwodo, U. U., Green, E., \& Okoh, A. I. (2016). Quantitative PCR Detection and Characterisation of Human Adenovirus, Rotavirus and Hepatitis A Virus in Discharged Effluents of Two Wastewater Treatment Facilities in the Eastern Cape, South Africa. Food and Environmental Virology, 8(4), 262-274. https://doi.org/10.1007/s12560-016-9246-4.

Adeniji, J. A., \& Faleye, T. O. C. (2014). Isolation and identification of enteroviruses from sewage and sewage-contaminated water in lagos, Nigeria. Food and Environmental Virology, 6(2), 75-86. https://doi.org/10.1007/s12560-014-9137-5.

Adewumi, J. R., \& Oguntuase, A. M. (2016). Planning of wastewater reuse programme in Nigeria. Consilience, 15(1), 1-33. https:// doi.org/10.7916/D82F7N87.

Afrad, M. H., Avzun, T., Haque, J., Haque, W., Hossain, M. E., Rahman, A. F. M. R., et al. (2018). Detection of enteric- and nonenteric adenoviruses in gastroenteritis patients, Bangladesh, 2012-2015. Journal of Medical Virology, 90(4), 677-684. https ://doi.org/10.1002/jmv.25008.

Ahmed, W., Angel, N., Edson, J., Bibby, K., Bivins, A., O’Brien, J. W., et al. (2020a). First confirmed detection of SARS-CoV-2 in untreated wastewater in Australia: A proof of concept for the wastewater surveillance of COVID-19 in the community. Science of the Total Environment, 728, 138764. https://doi.org/10.1016/j. scitotenv.2020.138764. 
Ahmed, W., Payyappat, S., Cassidy, M., Harrison, N., \& Besley, C. (2020b). Sewage-associated marker genes illustrate the impact of wet weather overflows and dry weather leakage in urban estuarine waters of Sydney, Australia. Science of the Total Environment, 705, 135390. https://doi.org/10.1016/j.scitotenv.2019.135390.

Akdag, A. I., Gupta, S., Khan, N., Upadhayay, A., \& Ray, P. (2020). Epidemiology and clinical features of rotavirus, adenovirus, and astrovirus infections and coinfections in children with acute gastroenteritis prior to rotavirus vaccine introduction in Meerut, North India. Journal of Medical Virology, 92(8), 1102-1109. https://doi.org/10.1002/jmv.25645.

Ali, M. A., Al-Herrawy, A. Z., \& El-Hawaary, S. E. (2004). Detection of enteric viruses, giardia and cryptosporidium in two different types of drinking water treatment facilities. Water Research, 38(18), 3931-3939. https://doi.org/10.1016/j.watre s.2004.06.014.

Aliabadi, N., Antoni, S., Mwenda, J. M., Weldegebriel, G., Biey, J. N. M., Cheikh, D., et al. (2019). Global impact of rotavirus vaccine introduction on rotavirus hospitalisations among children under 5 years of age, 2008-16: Findings from the global rotavirus surveillance network. The Lancet Global Health, 7(7), e893-e903. https://doi.org/10.1016/S2214-109X(19)30207-4.

Alidjinou, E. K., Sane, F., Firquet, S., Lobert, P. E., \& Hober, D. (2019). Resistance of enteric viruses on fomites. Intervirology, 61(5), 205-213. https://doi.org/10.1159/000448807.

Al-Sadeq, D. W., Majdalawieh, A. F., Mesleh, A. G., Abdalla, O. M., \& Nasrallah, G. K. (2018). Laboratory challenges in the diagnosis of hepatitis E Virus. Journal of Medical Microbiology, 67(4), 466-480. https://doi.org/10.1099/jmm.0.000706.

Ambert-Balay, K., Lorrot, M., Bon, F., Giraudon, H., Kaplon, J., Wolfer, M., et al. (2008). Prevalence and genetic diversity of aichi virus strains in stool samples from community and hospitalized patients. Journal of Clinical Microbiology, 46(4), 12521258. https://doi.org/10.1128/JCM.02140-07.

Amdiouni, H., Faouzi, A., Fariat, N., Hassar, M., Soukri, A., \& Nourlil, J. (2012). Detection and molecular identification of human adenoviruses and enteroviruses in wastewater from Morocco. Letters in Applied Microbiology, 54(4), 359-366. https://doi. org/10.1111/j.1472-765X.2012.03220.x.

Amdiouni, H. A., Maunula, L., Al-Shuwaikh, A. M., \& Nourlil, J. (2017). Comparison of Two Virus Concentration Methods for Enteric Viruses Detection in Moroccan Wastewater and Treated Effluent. Iraqi journal of Medical Sciences, 15(1), 27-38. https:// doi.org/https://doi.org/10.22578/ijms.15.1.5

Amoroso, M. G., Langellotti, A. L., Russo, V., Martello, A., Monini, M., Di Bartolo, I., et al. (2020). Accumulation and depuration kinetics of rotavirus in mussels experimentally contaminated. Food and Environmental Virology, 12(1), 48-57. https://doi. org/10.1007/s12560-019-09413-0.

Andreasi, M. S. A., Cardoso, D. D. D. D. P., Fernandes, S. M., Tozetti, I. A., Borges, A. M. T., Fiaccadori, F. S., et al. (2008). Adenovirus, Calicivirus and Astrovirus Detection in Fecal Samples of Hospitalized Children With Acute Gastroenteritis from Campo Grande, MS, Brazil. Memorias do Instituto Oswaldo Cruz, 103(7), 741-744. https://doi.org/10.1590/S0074-0276200800 0700020.

Araud, E., Di Caprio, E., Ma, Y., Lou, F., Gao, Y., Kingsley, D., et al. (2016). Thermal inactivation of enteric viruses and bioaccumulation of enteric foodborne viruses in live oysters (Crassostrea virginica). Applied and Environmental Microbiology, 82(7), 2086-2099. https://doi.org/10.1128/AEM.03573-15.

Asghar, H., Diop, O. M., Weldegebriel, G., Malik, F., Shetty, S., El Bassioni, L., et al. (2014). Environmental surveillance for polioviruses in the global polio eradication initiative. Journal of Infectious Diseases, 210(Suppl 1), S294-S303. https://doi. org/10.1093/infdis/jiu384.
Atmar, R. L., Opekun, A. R., Gilger, M. A., Estes, M. K., Crawford, S. E., Neill, F. H., \& Graham, D. Y. (2008). Norwalk Virus Shedding After Experimental Human Infection. Emerging Infectious Diseases, 14(10), 1553-1557. https://doi.org/10.3201/eid14 10.080117.

Azzam, M. I., Ezzat, S. M., El-dougdoug, K. A., \& Badawi, A. (2014). Rapid Quantitative Detection of Enteric Viruses in River Nile and Drainage Water, Egypt. Egyptian Journal of Virology, (January).

Azzouzi, L. M. I., Senouci, S., El Qazoui, M., Oumzil, H., \& Naciri, M. (2017). Detection of enterovirus in mussels from Morocco by cell culture and real-time PCR. African Journal of Biotechnology, 16(34), 1791-1799. https://doi.org/10.5897/ajb2017.16104.

Babalola, M., Adeoyo, O., \& Odesanya, O. (2019). Detection of Norovirus from Fresh and Vended Periwinkles (Tympanotonus fuscatus var radula) in Nigeria. Egyptian Journal of Food Science, 47(1), 0-0. https://doi.org/https://doi.org/10.21608/ ejfs.2019.15979.1015

Baggen, J., Thibaut, H. J., Strating, J. R. P. M., \& Kuppeveld, F. J. M. (2018). The life cycle of non-polio enteroviruses and how to target it. Nature Reviews Microbiology, 16, 368-381. https://doi. org/10.1038/s41579-018-0005-4.

Baker, G. (2016). Food safety impacts from post-harvest processing procedures of molluscan shellfish. Foods, 5(4), 29. https://doi. org/10.3390/foods5020029.

Baker, K. K., Senesac, R., Sewell, D., Sen Gupta, A., Cumming, O., \& Mumma, J. (2018). Fecal Fingerprints of enteric pathogen contamination in public environments of Kisumu, Kenya, associated with human sanitation conditions and domestic animals. Environmental Science and Technology, 52(18), 10263-10274. https://doi.org/10.1021/acs.est.8b01528.

Bányai, K., Estes, M. K., Martella, V., \& Parashar, U. D. (2018). Viral gastroenteritis. The Lancet, 392(10142), 175-186. https://doi. org/10.1016/S0140-6736(18)31128-0.

Bartsch, S. M., Lopman, B. A., Ozawa, S., Hall, A. J., \& Lee, B. Y. (2016). Global economic burden of norovirus gastroenteritis. PLoS One, 11(4), 1-16. https://doi.org/10.1371/journ al.pone.0151219.

Baert, L., Mattison, K., Loisy-Hamon, F., Harlow, J., Martyres, A., Lebeau, B., et al. (2011). Review: Norovirus prevalence in Belgian, Canadian and French fresh produce: A threat to human health? International Journal of FoodMicrobiology, 151(3), 261-269. https://doi.org/10.1016/j.ijfoodmicro.2011.09.013.

Bauza, V., Madadi, V., Ocharo, R., Nguyen, T. H., \& Guest, J. S. (2019). Enteric pathogens from water, hands, surface, soil, drainage ditch, and stream exposure points in a low-income neighborhood of Nairobi, Kenya. Science of the Total Environment, 709, 135344. https://doi.org/10.1016/j.scitotenv.2019.135344.

Béji-Hamza, A., Hassine-Zaafrane, M., Khélifi-Gharbi, H., Della Libera, S., Iaconelli, M., Muscillo, M., et al. (2015). Hepatitis E virus genotypes 1 and 3 in wastewater samples in Tunisia. Archives of Virology, 160(1), 183-189. https://doi.org/10.1007/ s00705-014-2251-8.

Béji-Hamza, A., Khélifi-Gharbi, H., Hassine-Zaafrane, M., Della Libera, S., Iaconelli, M., Muscillo, M., et al. (2014). Qualitative and quantitative assessment of hepatitis a virus in wastewaters in Tunisia. Food and Environmental Virology, 6(4), 246-252. https://doi.org/10.1007/s12560-014-9163-3.

Belguith, K., Hassen, A., Bouslama, L., Khira, S., \& Aouni, M. (2007). Enterovirus Circulation in Wastewater and Behavior of Some Serotypes During Sewage Treatment in Monastir, Tunisia. Journal of Environmental Health, 69(10), 52-57. http://www.jstor .org/stable/26327280

Bellou, M., Kokkinos, P., \& Vantarakis, A. (2013). Shellfish-borne viral outbreaks: A systematic review. Food and Environmental Virology, 5(1), 13-23. https://doi.org/10.1007/s12560-012-9097-6. 
Benabbes, L., Anga, L., Faouzi, A., Rhaissi, H., \& Nourlil, J. (2013a). Detection of Human Enterovirus and Adenovirus in Shellfish Collected in Morocco Mediterranean Coast. Journal of Microbiology, Biotechnology and Food Sciences, 3(2), 97-100. https:// doi.org/https://doi.org/10.15414/jmbfs.2017.7.2.97-100

Benabbes, L., Ollivier, J., Schaeffer, J., Parnaudeau, S., Rhaissi, H., Nourlil, J., \& Le Guyader, F. S. (2013b). Norovirus and other human enteric viruses in Moroccan shellfish. Food and Environmental Virology, 5(1), 35-40. https://doi.org/10.1007/s1256 0-012-9095-8.

Berendes, D. M., Kirby, A. E., Clennon, J. A., Agbemabiese, C., Ampofo, J. A., Armah, G. E., et al. (2018). Urban sanitation coverage and environmental fecal contamination: links between the household and public environments of Accra, Ghana. PLoS ONE, 13(7), 1-19. https://doi.org/10.1371/journal.pone.0199304.

Bergallo, M., Galliano, I., Montanari, P., Rassu, M., \& Daprà, V. (2018). Aichivirus in children with diarrhea in Northern Italy. Intervirology, 60(5), 196-200. https://doi.org/10.1159/00048 7051.

Bichai, F., \& Smeets, P. W. M. H. (2013). Using QMRA-based regulation as a water quality management tool in the water security challenge: Experience from the Netherlands and Australia. Water Research, 47(20), 7315-7326. https://doi.org/10.1016/j.watre s.2013.09.062.

Bishop, R., \& Kirkwood, C. (2008). Enteric Viruses. In B. W. J. Mahy \& M. H. V. Van Regenmortel (Eds.), Encyclopedia of Virology (pp. 116-123). London: Academic Press. https://doi.org/https:// doi.org/10.1016/B978-012374410-4.00386-1

Bivins, A., North, D., Ahmad, A., Ahmed, W., Alm, E., Been, F., et al. (2020). Wastewater-based epidemiology: Global Collaborative to maximize contributions in the fight against COVID-19. Environmental Science and Technology, 54(13), 7754-7757. https:// doi.org/10.1021/acs.est.0c02388.

Blinkova, O., Rosario, K., Li, L., Kapoor, A., Slikas, B., Bernardin, F., et al. (2009). Frequent detection of highly diverse variants of cardiovirus, cosavirus, bocavirus, and circovirus in sewage samples collected in the United States. Journal of Clinical Microbiology, 47(11), 3507-3513. https://doi.org/10.1128/JCM.01062-09.

Bosch, A. (1998). Human Enteric Viruses in the Water Environment: A Minireview. International Microbiology, 1(3), 191-196. https ://doi.org/10.2436/im.v1i3.39.

Bosch, A., Pintó, R. M., \& Guix, S. (2014). Human astroviruses. Clinical Microbiology Reviews, 27(4), 1048-1074. https://doi. org/10.1128/CMR.00013-14.

Bouseettine, R., Hassou, N., Bessi, H., \& Ennaji, M. (2019). Waterborne Transmission of Enteric Viruses and Their Impact on Public Health. In M. M. Ennaji (Ed.), Emerging and Reemerging Viral Pathogens (pp. 907-932). London: Academic Press. https ://doi.org/10.1111/cjag.12228.

Boyce, M. R., Katz, R., \& Standley, C. J. (2019). Risk Factors for Infectious Diseases in Urban Environments of sub-Saharan Africa: A Systematic Review and Critical Appraisal of Evidence. Tropical Medicine and Infectious Disease. https://doi.org/10.3390/tropi calmed4040123.

Brister, J. R., Chodosh, J., Curiel, D. T., Heim, A., Jones, M. S., Kajon, A., et al. (2019). HAdV Working Group. Retrieved May 20, 2020 from http://hadvwg.gmu.edu/.

Burkhardt, W., \& Calci, K. R. (2000). Selective accumulation may account for shellfish-associated viral illness. Applied and Environmental Microbiology, 66(4), 1375-1378. https://doi. org/10.1128/AEM.66.4.1375-1378.2000

Campos, G. S., Sampaio, M. L. S., Menezes, A. D. L., Tigre, D. M., Costa, L. F. M., Chinalia, F. A., \& Sardi, S. I. (2016). Human bocavirus in acute gastroenteritis in children in Brazil. Journal of Medical Virology, 88, 166-170. https://doi.org/10.1002/ jmv.24293.
Cassidy, H., Poelman, R., Knoester, M., Leer-Buter, C. C. V., \& Niesters, H. G. M. (2018). Enterovirus D68 -the new polio? Frontiers in Microbiology, 9, 2677. https://doi.org/10.3389/ fmicb.2018.02677.

Chan, M. C. W., Hu, Y., Chen, H., Podkolzin, A. T., Zaytseva, E. V., Komano, J., et al. (2017). Global Spread of Norovirus GII.17 Kawasaki 308, 2014-2016. Emerging Infectious Diseases, 23(8), 1350-1354. https://doi.org/https://doi.org/10.3201/ eid2308.161138

Chan, M. C. W., Lee, N., Hung, T. N., Kwok, K., Cheung, K., Tin, E. K. Y., et al. (2015). Rapid Emergence and Predominance of a Broadly Recognizing and Fast-Evolving Norovirus GII.17 Variant in Late 2014. Nature Communications, 6. https://doi. org/https://doi.org/10.1038/ncomms10061

Chen, B. S., Lee, H. C., Lee, K. M., Gong, Y. N., \& Shih, S. R. (2020). Enterovirus and encephalitis. Frontiers in Microbiology, 11, 1-15. https://doi.org/10.3389/fmicb.2020.00261.

Chhabra, P., de Graaf, M., Parra, G. I., Chan, M. C. W., Green, K., Martella, V., et al. (2019). Updated classification of norovirus genogroups and genotypes. The Journal of General Virology, 100(10), 1393-1406. https://doi.org/10.1099/jgv.0.001318.

Chigor, V. N., \& Okoh, A. I. (2012a). Quantitative RT-PCR detection of hepatitis A virus, rotaviruses and enteroviruses in the Buffalo River and source water dams in the Eastern Cape Province of South Africa. International Journal of Environmental Research and Public Health, 9(11), 4017-4032. https://doi. org/10.3390/ijerph9114017.

Chigor, V. N., \& Okoh, A. I. (2012b). Quantitative Detection and Characterization of Human Adenoviruses in the Buffalo River in the Eastern Cape Province of South Africa. Food and Environmental Virology, 4, 198-208. https://doi.org/10.1007/s1256 0-012-9090-0.

Chigor, V. N., Sibanda, T., \& Okoh, A. I. (2014). Assessment of the risks for human health of adenoviruses, hepatitis a virus, rotaviruses and enteroviruses in the Buffalo River and three source water dams in the Eastern Cape. Food and Environmental Virology, 6(2), 87-98. https://doi.org/10.1007/s1256 0-014-9138-4.

Christensen, A., Kesti, O., Elenius, V., Eskola, A. L., Døllner, H., Altunbulakli, C., et al. (2019). Human bocaviruses and paediatric infections. The Lancet Child and Adolescent Health, 3(6), 418-426. https://doi.org/10.1016/S2352-4642(19)30057-4.

Chuchaona, W., Khamrin, P., Yodmeeklin, A., Kumthip, K., Saikruang, W., Thongprachum, A., et al. (2017). Detection and characterization of aichi virus 1 in pediatric patients with diarrhea in Thailand. Journal of Medical Virology, 89, 234-238. https:// doi.org/10.1002/jmv.

Cordey, S., Brito, F., Vu, D. L., Turin, L., Kilowoko, M., Kyungu, E., et al. (2016). Astrovirus VA1 identified by next-generation sequencing in a nasopharyngeal specimen of a febrile Tanzanian child with acute respiratory disease of unknown etiology. Emerging Microbes and Infections, 5(7), 2-4. https://doi.org/10.1038/ emi.2016.67.

Coudray-Meunier, C., Fraisse, A., Mokhtari, C., Martin-Latil, S., Roque-Afonso, A. M., \& Perelle, S. (2014). Hepatitis A Virus Subgenotyping Based on RT-qPCR Assays. BMC Microbiology, 14(1). https://doi.org/https://doi.org/10.1186/s12866-014-0296-1

Crawford, S. E., Ramani, S., Tate, J. E., Parashar, U. D., Svensson, L., Hagbom, M., et al. (2017). Rotavirus Infection. Nature Reviews Disease Primers, 3, 17083. https://doi.org/10.1038/nrdp.2017.83.

De Graaf, M., Van Beek, J., \& Koopmans, M. P. G. (2016). Human norovirus transmission and evolution in a changing world. Nature Reviews Microbiology, 14(7), 421-433. https://doi.org/10.1038/ nrmicro.2016.48.

Denner, J. (2019). Hepatitis E Virus (HEV) - The Future. Viruses, 11(3), 1-11. https://doi.org/10.3390/v11030251. 
Diez-Valcarce, M., Castro, C. J., Marine, R. L., Halasa, N., Mayta, H., Saito, M., et al. (2018). Genetic diversity of human sapovirus across the Americas. Journal of Clinical Virology, 104, 65-72. https://doi.org/10.1016/j.jcv.2018.05.003.

Donato, C., \& Vijaykrishna, D. (2017). The broad host range and genetic diversity of mammalian and avian astroviruses. Viruses, 9(5), 1-18. https://doi.org/10.3390/v9050102.

Dongdem, J. T., Damanka, S., \& Asmah, R. (2011). Molecular isolation of human norovirus and astrovirus in tap water by RT-PCR. International Research Journal of Biochemistry and Bioinformatics, 1(6), 131-138.

Donia, D., Dell'Amico, M. C., Petrinca, A. R., Martinucci, I., Mazzei, M., Tolari, F., \& Divizia, M. (2012). Presence of hepatitis E RNA in mussels used as bio-monitors of viral marine pollution. Journal of Virological Methods, 186(1-2), 198-202. https://doi. org/10.1016/j.jviromet.2012.06.007.

Drexler, J. F., Baumgarte, S., Luna, L., de Souza, K., Eschbach-Bludau, M., Lukashev, A. N., \& Drosten, C. (2011). Aichi virus shedding in high concentrations in patients with acute diarrhea. Emerging Infectious Diseases, 17(8), 1544-1547. https://doi.org/10.3201/ eid1708.101556.

Ehlers, M. M., Grabow, W. O. K., \& Pavlov, D. N. (2005). Detection of enteroviruses in untreated and treated drinking water supplies in South Africa. Water Research, 39(11), 2253-2258. https://doi. org/10.1016/j.watres.2005.04.014.

El Moqri, N., El Mellouli, F., Hassou, N., Benhafid, M., Abouchoaib, N., \& Etahiri, S. (2019). Norovirus Detection at Oualidia Lagoon, a Moroccan Shellfish Harvesting Area, by Reverse Transcription PCR Analysis. Food and Environmental Virology, 11(3), 268-273. https://doi.org/10.1007/s12560-019-09386-0.

Elamri, D. E., Aouni, M., Parnaudeau, S., \& Le Guyader, F. S. (2006). Detection of human enteric viruses in shellfish collected in Tunisia. Letters in Applied Microbiology, 43(4), 399-404. https://doi. org/10.1111/j.1472-765X.2006.01978.x.

Elmahdy, E. M., Ahmed, N. I., Shaheen, M. N. F., Mohamed, E. C. B., \& Loutfy, S. A. (2019). Molecular detection of human adenovirus in urban wastewater in Egypt and among children suffering from acute gastroenteritis. Journal of Water and Health, 17(2), 287-294. https://doi.org/10.2166/wh.2019.303.

Elmahdy, E. M., Shaheen, M. N. F., Rizk, N. M., \& Saad-Hussein, A. (2020). Quantitative Detection of Human Adenovirus and Human Rotavirus Group A in Wastewater and El-Rahawy Drainage Canal Influencing River Nile in the North of Giza, Egypt. Food and Environmental Virology, (0123456789). https://doi. org/https://doi.org/10.1007/s12560-020-09429-x

El-Senousy, W. M., Abu Senna, A. S. M., Mohsen, N. A., Hasan, S. F., \& Sidkey, N. M. (2020). Clinical and Environmental Surveillance of Rotavirus Common Genotypes Showed High Prevalence of Common P Genotypes in Egypt. Food and Environmental Virology, 12(2), 99-117. https://doi.org/10.1007/s12560-02009426-0.

El-Senousy, W. M., Barakat, A. B., Ghanem, H. E., \& Kamel, M. A. (2013a). Molecular Epidemiology of Human Adenoviruses and Rotaviruses as Candidate Viral Indicators in the Egyptian Sewage and Water Samples. World Applied Sciences Journal, 27(10), 1235-1247. https://doi.org/10.5829/idosi.wasj.2013.27.10.81200

El-Senousy, W. M., Costafreda, M. I., Pintó, R. M., \& Bosch, A. (2013b). Method validation for norovirus detection in naturally contaminated irrigation water and fresh produce. International Journal of Food Microbiology, 167(1), 74-79. https://doi. org/10.1016/j.ijfoodmicro.2013.06.023.

El-Senousy, W. M., El-Gamal, M. S., Kamel, M. M., \& El-Mahdy, E. M. (2014). Prevalence of Human and Animal Rotaviruses and HEV in Egyptian Nile Water Resources. World Applied
Sciences Journal, 32(11), 2218-2228. https://doi.org/10.5829/ idosi.wasj.2014.32.11.91125.

El-Senousy, W. M., Guix, S., Abid, I., Pintó, R. M., \& Bosch, A. (2007). Removal of astrovirus from water and sewage treatment plants, evaluated by a competitive reverse transcriptionPCR. Applied and Environmental Microbiology, 73(1), 164167. https://doi.org/10.1128/AEM.01748-06.

El-Senousy, W. M., Ragab, A. M. E. S., \& Handak, E. M. A. E. H. (2015). Prevalence of rotaviruses groups A and C in Egyptian children and aquatic environment. Food and Environmental Virology, 7(2), 132-141. https://doi.org/10.1007/s1256 0-015-9184-6.

Ezeh, A., Oyebode, O., Satterthwaite, D., Chen, Y. F., Ndugwa, R., Sartori, J., et al. (2017). The history, geography, and sociology of slums and the health problems of people who live in slums. The Lancet, 389(10068), 547-558. https://doi.org/10.1016/ S0140-6736(16)31650-6.

Farkas, K., Walker, D. I., Adriaenssens, E. M., McDonald, J. E., Hillary, L. S., Malham, S. K., \& Jones, D. L. (2020). Viral indicators for tracking domestic wastewater contamination in the aquatic environment. Water Research, 181, 115926. https ://doi.org/10.1016/j.watres.2020.115926.

Fayomi, G. U., Mini, S. E., Fayomi, O. S. I., Owodolu, T., Ayoola, A. A., \& Wusu, O. (2019). A mini review on the impact of sewage disposal on environment and ecosystem. IOP Conference Series: Earth and Environmental Science, 331(012040), 1-6. https://doi.org/10.1088/1755-1315/331/1/012040.

Fioretti, J. M., Rocha, M. S., Fumian, T. M., Ginuino, A., da Silva, T. P., de Assis, M. R., et al. (2016). Occurrence of human sapoviruses in wastewater and stool samples in Rio De Janeiro, Brazil. Journal of Applied Microbiology, 121(3), 855-862. https ://doi.org/10.1111/jam.13205.

Flannery, J., Keaveney, S., \& Doré, W. (2009). Use of FRNA bacteriophages to indicate the risk of Norovirus contamination in Irish oysters. Journal of Food Protection, 72(11), 2358-2362. https:// doi.org/10.4315/0362-028X-72.11.2358.

Fong, T. T., \& Lipp, E. K. (2005). Enteric viruses of humans and animals in aquatic environments: health risks, detection, and potential water quality assessment tools. Microbliology and Molecular Biology Reviews, 69(2), 357-371. https://doi. org/10.1128/MMBR.69.2.357.

Fusco, G., Anastasio, A., Kingsley, D. H., Amoroso, M. G., Pepe, T., Fratamico, P. M., et al. (2019). Detection of hepatitis A virus and other enteric viruses in shellfish collected in the Gulf of Naples, Italy. International Journal of Environmental Research and Public Health, 16, 2588. https://doi.org/10.3390/ ijerph16142588.

Fusco, G., Aprea, G., Galiero, G., Guarino, A., \& Viscardi, M. (2013). Escherichia coli, Salmonella spp., Hepatitis A Virus and Norovirus in Bivalve Molluscs in Southern Italy. Veterinaria Italiana, 49(1), 55-58.

Gad, M. A., Allayeh, A. K., Elmahdy, E. M., Shaheen, M. N. F., Rizk, N. M., Al-Herrawy, A. Z., et al. (2019). Genotyping and Interaction-Reality of Acanthamoeba, Enteric Adenovirus and Rotavirus in Drinking Water, Egypt. Egyptian Journal of Aquatic Biology and Fisheries, 23(2), 65-79. https://doi.org/https://doi. org/10.21608/ejabf.2019.29299

Gao, S., Li, D., Zha, E., Zhou, T., Wang, S., \& Yue, X. (2015). Surveillance of hepatitis E virus contamination in shellfish in China. International Journal of Environmental Research and Public Health, 12(2), 2026-2036. https://doi.org/10.3390/ijerph1202 02026.

Gharbi-khelifi, H., Sdiri, K., Ferre, V., Harrath, R., Berthome, M., Billaudel, S., \& Aouni, M. (2007). A 1-year study of the epidemiology of hepatitis A virus in Tunisia. Clinical 
Microbiology and Infection, 13(1), 25-32. https://doi.org/10.1 111/j.1469-0691.2006.01588.x.

Gibson, K. E. (2014). Viral pathogens in water: occurrence, public health impact, and available control strategies. Current Opinion in Virology, 4, 50-57. https://doi.org/10.1016/j.covir o.2013.12.005.

Gibson, K. E., Opryszko, M. C., Schissler, J. T., Guo, Y., \& Schwab, K. J. (2011). Evaluation of human enteric viruses in surface water and drinking water resources in Southern Ghana. American Journal of Tropical Medicine and Hygiene, 84(1), 20-29. https://doi. org/10.4269/ajtmh.2011.10-0389.

Godfrey, O., Zhang, W., Amponsem-Boateng, C., Oppong, T. B., Zhao, Q., \& Li, D. (2020). Evidence of rotavirus vaccine impact in subSaharan Africa: Systematic review and meta-analysis. PLoS ONE, 15(4), e0232113. https://doi.org/10.1371/journal.pone.0232113.

Gómez-Rial, J., Rivero-Calle, I., Salas, A., \& Martinón-Torres, F. (2020). Rotavirus and autoimmunity. Journal of Infection, 81(2), 183-189. https://doi.org/10.1016/j.jinf.2020.04.041.

Goyal, S. M., Adams, W. N., O’Malley, M. L., \& Lear, D. W. (1984). Human pathogenic viruses at sewage sludge disposal sites in the Middle Atlantic region. Applied and Environmental Microbiology, 48(4), 758-763. https://doi.org/10.1128/ aem.48.4.758-763.1984.

Grabow, W. O. K., Botma, K. L., De Villiers, J. C., Clay, C. G., \& Erasmus, B. (1999). Assessment of cell culture and polymerase chain reaction procedures for the detection of polioviruses in wastewater. Bulletin of the World Health Organization, 77(12), 973-980.

Grabow, W. O. K., Taylor, M. B., \& De Villiers, J. C. (2001). New methods for the detection of viruses: call for review of drinking water quality guidelines. Water Science and Technology, 43(12), 1-8. https://doi.org/10.2166/wst.2001.0703.

Graham, J. P., \& Polizzotto, M. L. (2013). Pit Latrines and Their Impacts on Groundwater Quality:: A Systematic Review. Environmental Health Perspectives, 121(5), 521-530. https://doi. org/10.1289/ehp.1206028.

Greening, G. E., \& Cannon, J. L. (2016). Human and Animal Viruses in Food (Including Taxonomy of Enteric Viruses). In S. Goyal \& J. Cannon (Eds.), Viruses in Foods. Food Microbiology and Food Safety. (pp. 5-57). Cham: Springer.

Guerrero-Latorre, L., Carratala, A., Rodriguez-Manzano, J., Calgua, B., Hundesa, A., \& Girones, R. (2011). Occurrence of waterborne enteric viruses in two settlements based in Eastern Chad: analysis of hepatitis E virus, hepatitis A virus and human adenovirus in water sources. Journal of Water and Health, 9(3), 515-524. https://doi.org/10.2166/wh.2011.126.

Guido, M., Tumolo, M. R., Verri, T., Romano, A., Serio, F., De Giorgi, M., et al. (2016). Human bocavirus: current knowledge and future challenges. World Journal of Gastroenterology, 22(39), 8684-8697. https://doi.org/10.3748/wjg.v22.i39.8684.

Habitat, U. N. (2013). State of the world's cities 2012/2013: prosperity of cities. London, Routledge. https://doi.org/10.4324/97802 03756171.

Hall, A. J. (2012). Noroviruses: The perfect human pathogens? Journal of Infectious Diseases, 205(11), 1622-1624. https://doi. org/10.1093/infdis/jis251.

Hamkar, R., Yahyapour, Y., Noroozi, M., Nourijelyani, K., Jalilvand, S., Adibi, L., et al. (2010). Prevalence of rotavirus, adenovirus, and astrovirus infections among patients with acute gastroenteritis in, Northern Iran. Iranian Journal of Public Health, 39(2), $45-51$.

Hamza Ewess, H. A. (2016). Detection and Characterization of Hepatitis A Virus Circulating in Egyptian Environment. Cairo University.

Hamza, H., Leifels, M., Wilhelm, M., \& Hamza, I. A. (2017). Relative Abundance of Human Bocaviruses in Urban Sewage in Greater
Cairo, Egypt. Food and Environmental Virology, 9(3), 304-313. https://doi.org/10.1007/s12560-017-9287-3.

Hamza, I. A., Jurzik, L., Wilhelm, M., \& Überla, K. (2009). Detection and quantification of human bocavirus in river water. Journal of General Virology, 90(11), 2634-2637. https://doi.org/10.1099/ vir.0.013557-0.

Hansman, G. S., Oka, T., Sakon, N., \& Takeda, N. (2007). Antigenic diversity of human sapoviruses. Emerging Infectious Diseases, 13(10), 1519-1525. https://doi.org/10.3201/eid1310.070402.

Haramoto, E., Malla, B., Thakali, O., \& Kitajima, M. (2020). First environmental surveillance for the presence of SARS-CoV-2 RNA in wastewater and river water in Japan. Science of the Total Environment, 737, 140405. https://doi.org/10.1016/j.scito tenv.2020.140405.

Hassaine, A., Gharbi, J., Harrath, R., Harrak, R., Chait, A., Aouni, M., et al. (2011). In Search of Enteroviruses in Water Media in Marrakech. African Journal of Microbiology Research, 5(16), 2380-2384. https://doi.org/10.5897/AJMR09.462.

Hassard, F., Gwyther, C. L., Farkas, K., Andrews, A., Jones, V., Cox, B., et al. (2016). Abundance and distribution of enteric bacteria and viruses in coastal and estuarine sediments-a review. Frontiers in Microbiology, 7, 1692. https://doi.org/10.3389/fmicb .2016.01692.

Hassine, M., Sdiri, K., Riabi, S., Beji, A., Aouni, Z., \& Aouni, M. (2010). Détection des virus entériques dans les Eaux Usées de la Région de Monastir par RT-PCR. La Tunisie Medicale, 88(2), $70-75$.

Hassine-Zaafrane, M., Kaplon, J., Ben Salem, I., Sdiri-Loulizi, K., Sakly, N., Pothier, P., et al. (2015). Detection and genotyping of group A rotaviruses isolated from sewage samples in Monastir, Tunisia Between April 2007 and April 2010. Journal of Applied Microbiology, 119(5), 1443-1453. https://doi.org/10.1111/ jam.12920.

Hassine-Zaafrane, M., Sdiri-Loulizi, K., Kaplon, J., Salem, I. Ben., Pothier, P., Aouni, M., \& Ambert-Balay, K. (2014). Molecular detection of human noroviruses in influent and effluent samples from two biological sewage treatment plants in the region of Monastir, Tunisia. Food and Environmental Virology, 6(2), 125131. https://doi.org/10.1007/s12560-014-9147-3.

Hassou, N., Bouseettine, R., Abouchoaib, N., \& Ennaji, M. M. (2019). Enteric Adenoviruses: Emerging of a Public Health Threat. In M. M. Ennaji (Ed.), Emerging and Reemerging Viral Pathogens. Volume 1: Fundamental and Basic Virology Aspects of Human, Animal and Plant Pathogens (pp. 879-905). London: Elsevier Inc. https://doi.org/https://doi.org/10.1016/B978-0-12-81940 0-3.00039-9

Hellmér, M., Paxéus, N., Magnius, L., Enache, L., Arnholm, B., Johansson, A., et al. (2014). Detection of Pathogenic Viruses in Sewage Provided Early Warnings of Hepatitis A Virus and Norovirus Outbreaks. Applied and Environmental Microbiology, 80(21), 6771-6781. https://doi.org/10.1128/AEM.01981-14.

Hendriksen, R. S., Lukjancenko, O., Munk, P., Hjelms $\varnothing$, M. H., Verani, J. R., Ng'eno, E., et al. (2019). Pathogen Surveillance in the Informal Settlement, Kibera, Kenya Using a Metagenomics Approach. PLoS ONE, 14(10), 1-15. https://doi.org/10.1371/ journal.pone.0222531.

Herbig, F. J. W. (2019). Talking dirty - effluent and sewage irreverence in South Africa: A conservation crime perspective. Cogent Social Sciences, 5(1), 1701359. https://doi.org/10.1080/23311 886.2019.1701359.

Hoa-Tran, T. N., Nakagomi, O., Dao, A. T. H., Nguyen, A. T., Agbemabiese, C. A., Vu, H. M., et al. (2017). Molecular epidemiology of noroviruses detected in Vietnamese children with acute gastroenteritis from 2012 to 2015. Journal of Medical Microbiology, 66(1), 34-45. https://doi.org/10.1099/jmm.0.000417. 
Howard, G., Pedley, S., \& Tibatemwa, S. (2006). Quantitative microbial risk assessment to estimate health risks attributable to water supply: Can the technique be applied in developing countries with limited data? Journal of Water and Health, 4(1), 49-65. https://doi.org/10.2166/wh.2006.0004.

Huang, Y., Mao, P., \& Wang, H. (2010). Detection of, and frequent co-infection with, human bocavirus in faecal specimens from children in Wuhan, China. Clinical Microbiology and Infection, 16(5), 490-492. https://doi.org/10.1111/j.1469-0691.2009.02862 .x.

Iaconelli, M., Divizia, M., Della Libera, S., Di Bonito, P., \& La Rosa, G. (2016). Frequent detection and genetic diversity of human bocavirus in urban sewage samples. Food and Environmental Virology, 8(4), 289-295. https://doi.org/10.1007/s1256 0-016-9251-7.

Iaconelli, M., Valdazo-González, B., Equestre, M., Ciccaglione, A. R., Marcantonio, C., Della Libera, S., \& La Rosa, G. (2017). Molecular characterization of human adenoviruses in urban wastewaters using next generation and sanger sequencing. Water Research, 121, 240-247. https://doi.org/10.1016/j.watre s.2017.05.039.

Ibrahim, C., Cherif, N., Hammami, S., Pothier, P., \& Hassen, A. (2015). Quantification and Molecular Characterization of Norovirus After two Wastewater Treatment Procedures. Water, Air, and Soil Pollution, 226(6), 1-13. https://doi.org/10.1007/s1127 0-015-2402-x.

Ibrahim, C., Cherif, N., Hammami, S., Pothier, P., \& Hassen, A. (2016). Quantification and genotyping of rotavirus a within two wastewater treatment processes. Clean - Soil, Air, Water, 44(4), 393-401. https://doi.org/10.1002/clen.201400588.

Ibrahim, C., Hammami, S., Chérif, N., Mejri, S., Pothier, P., \& Hassen, A. (2019). Detection of Sapoviruses in two biological lines of Tunisian hospital wastewater treatment. International Journal of Environmental Health Research, 29(4), 400-413. https ://doi.org/10.1080/09603123.2018.1546835.

Ibrahim, C., Hammami, S., Mejri, S., Mehri, I., Pothier, P., \& Hassen, A. (2017a). Detection of aichi virus genotype B in two lines of wastewater treatment processes. Microbial Pathogenesis, 109, 305-312. https://doi.org/10.1016/j.micpath.2017.06.001.

Ibrahim, C., Hassen, A., Pothier, P., Mejri, S., \& Hammami, S. (2018). Molecular detection and genotypic characterization of enteric adenoviruses in a hospital wastewater. Environmental Science and Pollution Research, 25(11), 10977-10987. https ://doi.org/10.1007/s11356-018-1399-2.

Ibrahim, C., Mehri, I., Hammami, S., Mejri, S., Hassen, A., \& Pothier, P. (2017b). Removal of human astroviruses from hospital wastewater by two biological treatment methods: natural oxidizing lagoons and rotating biodisks. Desalination and Water Treatment, 89, 287-296. https://doi.org/10.5004/ dwt.2017.21356.

Iizuka, S., Oka, T., Tabara, K., Omura, T., Katayama, K., Takeda, N., \& Noda, M. (2010). Detection of sapoviruses and noroviruses in an outbreak of gastroenteritis linked genetically to shellfish. Journal of Medical Virology, 82, 1247-1254. https://doi.org/10.1002/jmv.

Iritani, N., Kaida, A., Abe, N., Kubo, H., Sekiguchi, J. I., Yamamoto, S. P., et al. (2014). Detection and genetic characterization of human enteric viruses in oyster-associated gastroenteritis outbreaks between 2001 and 2012 in Osaka City, Japan. Journal of Medical Virology, 86, 2019-2025. https://doi.org/10.1002/jmv.23883.

Japhet, M. O., Famurewa, O., Adesina, O. A., Opaleye, O. O., Wang, B., Höhne, M., et al. (2019). Viral gastroenteritis among children of 0-5 years in Nigeria: Characterization of the first Nigerian aichivirus, recombinant noroviruses and detection of a zoonotic astrovirus. Journal of Clinical Virology, 111, 4-11. https://doi. org/10.1016/j.jcv.2018.12.004.
Jebri, S., Jofre, J., Barkallah, I., Saidi, M., \& Hmaied, F. (2012). Presence and fate of coliphages and enteric viruses in three wastewater treatment plants effluents and activated sludge from Tunisia. Environmental Science and Pollution Research, 19(6), 21952201. https://doi.org/10.1007/s11356-011-0722-y.

Jiang, S. C. (2006). Human adenoviruses in water: occurrence and health implications: A critical review. Environmental Science and Technology, 40(23), 7132-7140. https://doi.org/10.1021/ es0608920.

Kaikkonen, S., Räsänen, S., Rämet, M., \& Vesikari, T. (2010). Aichi virus infection in children with acute gastroenteritis in Finland. Epidemiology and Infection, 138(8), 1166-1171. https://doi. org/10.1017/S0950268809991300.

Kamel, A. H., Ali, M. A., El-Nady, H. G., Aho, S., Pothier, P., \& Belliot, G. (2010). Evidence of the co-circulation of enteric viruses in sewage and in the population of greater Cairo. Journal of Applied Microbiology, 108(5), 1620-1629. https://doi.org/10.1 111/j.1365-2672.2009.04562.x.

Kamel, A. H., Ali, M. A., El-Nady, H. G., Deraz, A., Aho, S., Pothier, P., \& Belliot, G. (2011). Presence of enteric hepatitis viruses in the sewage and population of greater Cairo. Clinical Microbiology and Infection, 17(8), 1182-1185. https://doi.org/10.111 1/j.1469-0691.2011.03461.x.

Kapusinszky, B., Minor, P., \& Delwart, E. (2012). Nearly constant shedding of diverse enteric viruses by two healthy infants. Journal of Clinical Microbiology, 50(11), 3427-3434. https://doi. org/10.1128/JCM.01589-12.

Karamoko, Y., Ibenyassine, K., Mhand, R. A., Idaomar, M., \& Ennaji, M. M. (2005). Adenovirus detection in shellfish and urban sewage in Morocco (Casablanca Region) by the polymerase chain reaction. Journal of Virological Methods, 126(1-2), 135-137. https://doi.org/10.1016/j.jviromet.2005.02.003.

Karamoko, Y., Mhand, R. A., Idaomar, M., \& Ennaji, M. M. (2006a). Assessment of enterovirus contamination in mussel samples from Morocco. World Journal of Microbiology and Biotechnology, 22(2), 105-108. https://doi.org/10.1007/s11274-005-9003-6.

Karamoko, Y., Mhand, R. A., Idaomar, M., \& Ennaji, M. M. (2006b). Incidence of enteroviruses in groundwater from public baths of Mohammedia (Morocco). European Journal of Scientific Research, 13(2), 199-205.

Katukiza, A. Y., Ronteltap, M., van der Steen, P., Foppen, J. W. A., \& Lens, P. N. L. (2013a). Quantification of microbial risks to human health caused by waterborne viruses and bacteria in an urban slum. Journal of Applied Microbiology, 116(2), 447-463. https://doi.org/10.1111/jam.12368.

Katukiza, A. Y., Temanu, H., Chung, J. W., Foppen, J. W. A., \& Lens, P. N. L. (2013b). Genomic copy concentrations of selected waterborne viruses in a slum environment in Kampala, Uganda. Journal of Water and Health, 11(2), 358-370. https://doi. org/10.2166/wh.2013.184.

Kayembe, J. M., Thevenon, F., Laffite, A., Sivalingam, P., Ngelinkoto, P., Mulaji, C. K., et al. (2018). High levels of faecal contamination in drinking groundwater and recreational water due to poor sanitation, in the sub-rural neighbourhoods of Kinshasa, Democratic Republic of the Congo. International Journal of Hygiene and Environmental Health, 221(3), 400-408. https:// doi.org/10.1016/j.ijheh.2018.01.003.

Khanal, S., Ghimire, P., \& Dhamoon, A. S. (2018). The Repertoire of Adenovirus in Human Disease: The Innocuous to the Deadly. Biomedicines, 6(1). https://doi.org/https://doi.org/10.3390/biome dicines6010030

Khora, S. S. (2018). Risk from Viral Pathogens in Seafood. In A. M. Holban \& A. M. Grumezescu (Eds.), Handbook of Food Bioengineering, Diet, Microbiome and Health (pp. 439-481). London: Academic Press. https://doi.org/https://doi.org/10.1016/B978-012-811440-7.00015-6 
Kim, K. . Il., Kwon, W. J., Kim, Y. C., Kim, M. S., Hong, S., \& Do Jeong, H. (2016). Surveillance of aquatic animal viruses in seawater and shellfish in Korea. Aquaculture, 461, 17-24. https:// doi.org/10.1016/j.aquaculture.2016.03.053.

Kitajima, M., \& Gerba, C. P. (2015). Aichi Virus 1: environmental occurrence and behavior. Pathogens, 4(2), 256-268. https://doi. org/10.3390/pathogens4020256.

Kitajima, M., Rachmadi, A. T., Iker, B. C., Haramoto, E., \& Gerba, C. P. (2016). Genetically distinct genogroup IV norovirus strains identified in wastewater. Archives of Virology, 161(12), 35213525. https://doi.org/10.1007/s00705-016-3036-z.

Kitajima, M., Rachmadi, A. T., Iker, B. C., Haramoto, E., \& Gerba, C. P. (2018). Temporal variations in genotype distribution of human sapoviruses and aichi virus 1 in wastewater in Southern Arizona, United States. Journal of Applied Microbiology, 124(5), 1324-1332. https://doi.org/10.1111/jam.13712.

Kiulia, N. M., Mans, J., Mwenda, J. M., \& Taylor, M. B. (2014). Norovirus GII.17 Predominates in Selected Surface Water Sources in Kenya. Food and Environmental Virology, 6(4), 221-231. https:// doi.org/https://doi.org/10.1007/s12560-014-9160-6

Kiulia, N. M., Netshikweta, R., Page, N. A., Van Zyl, W. B., Kiraithe, M. M., Nyachieo, A., et al. (2010). The detection of enteric viruses in selected urban and rural river water and sewage in Kenya, with special reference to rotaviruses. Journal of Applied Microbiology, 109(3), 818-828. https://doi.org/10.111 1/j.1365-2672.2010.04710.x.

Kosulin, K. (2019). Intestinal HAdV infection: Tissue specificity, persistence, and implications for antiviral therapy. Viruses, 11(9), 15-21. https://doi.org/10.3390/v11090804.

Kottaridi, C., Bolanaki, E., \& Markoulatos, P. (2004). Amplification of echoviruses genomic regions by different RT-PCR protocols - a comparative study. Molecular and Cellular Probes, 18(4), 263-269. https://doi.org/10.1016/j.mcp.2004.02.003.

Kroneman, A., Vega, E., Vennema, H., Vinjé, J., White, P. A., Hansman, G., et al. (2013). Proposal for a unified norovirus nomenclature and genotyping. Archives of Virology, 158(10), 2059-2068. https://doi.org/10.1007/s00705-013-1708-5.

Kumar, M., Patel, A. K., Shah, A. V., Raval, J., Rajpara, N., Joshi, M., \& Joshi, C. G. (2020). First proof of the capability of wastewater surveillance for COVID-19 in India through detection of genetic material of SARS-CoV-2. Science of the Total Environment, 746, 141326. https://doi.org/10.1016/j.scitotenv.2020.141326.

La Bella, G., Martella, V., Basanisi, M. G., Nobili, G., Terio, V., \& La Salandra, G. (2017). Food-borne viruses in shellfish: investigation on norovirus and HAV presence in Apulia (SE Italy). Food and Environmental Virology, 9(2), 179-186. https://doi. org/10.1007/s12560-016-9273-1.

La Rosa, G., Della Libera, S., Iaconelli, M., Donia, D., Cenko, F., Xhelilaj, G., et al. (2016). Human bocavirus in children with acute gastroenteritis in Albania. Journal of Medical Virology, 88(5), 906-910. https://doi.org/10.1002/jmv.24415.

La Rosa, G., Iaconelli, M., Mancini, P., Bonanno Ferraro, G., Veneri, C., Bonadonna, L., et al. (2020). First detection of SARS$\mathrm{CoV}-2$ in untreated wastewaters in Italy. Science of the Total Environment, 736, 139652. https://doi.org/10.1016/j.scito tenv.2020.139652.

La Rosa, G., Manoochehr IaconelliPourshaban, M. M., \& Muscillo, M. (2010). Quantitative real-time PCR of enteric viruses in influent and effluent samples from wastewater treatment plants in Italy. Annali dell'Istituto superiore di sanita, 46(3), 226-273. https:// doi.org/10.4415/Ann_10_03_07.

La Rosa, G., Purpari, G., Guercio, A., Di Bella, S., Gucciardi, F., Proroga, Y. T. R., et al. (2018). Detection of human bocavirus species 2 and 3 in bivalve shellfish in Italy. Applied and Environmental Microbiology, 84(7), 4-11. https://doi.org/10.1128/ AEM.02754-17.
La Rosa, G., Sanseverino, I., Della Libera, S., Iaconelli, M., Ferrero, V. E. V., Barra Caracciolo, A., \& Lettieri, T. (2017). The impact of anthropogenic pressure on the virological quality of water from the Tiber River, Italy. Letters in Applied Microbiology, 65(4), 298-305. https://doi.org/10.1111/lam.12774.

Lapworth, D. J., Nkhuwa, D. C. W., Okotto-Okotto, J., Pedley, S., Stuart, M. E., Tijani, M. N., \& Wright, J. (2017). Urban groundwater quality in sub-Saharan Africa: Current status and implications for water security and public health. Hydrogeology Journal, 25(4), 1093-1116. https://doi.org/10.1007/s10040-016-1516-6.

Le Guyader, F. S., Le Saux, J. C., Ambert-Balay, K., Krol, J., Serais, O., Parnaudeau, S., et al. (2008). Aichi Virus, Norovirus, Astrovirus, Enterovirus, and Rotavirus Involved in Clinical Cases from a French Oyster-Related Gastroenteritis Outbreak. Journal of Clinical Microbiology, 46(12), 4011-4017. https:// doi.org/10.1128/JCM.01044-08.

Lee, E. J., Kim, H. S., Kim, H. S., Kim, J. S., Song, W., Kim, M., et al. (2016). Human Bocavirus in Korean Children with Gastroenteritis and Respiratory Tract Infections. BioMed Research International, 2016, 1-5. https://doi.org/10.1155/2016/75078 95.

Lees, D. (2000). Viruses and bivalve shellfish. International Journal of Food Microbiology, 59(1-2), 81-116. https://doi.org/10.1016/ S0168-1605(00)00248-8.

Leifels, M., Hamza, I. A., Krieger, M., Wilhelm, M., Mackowiak, M., \& Jurzik, L. (2016). From lab to lake - evaluation of current molecular methods for the detection of infectious enteric viruses in complex water matrices in an urban area. PLoS ONE, 11(11), 1-16. https://doi.org/10.1371/journal.pone.0167105.

Lemon, S. M., Ott, J. J., Van Damme, P., \& Shouval, D. (2018). Type A viral hepatitis: A summary and update on the molecular virology, epidemiology, pathogenesis and prevention. Journal of Hepatology, 68(1), 167-184. https://doi.org/10.1016/j.jhep.2017.08.034.

Levidiotou, S., Gartzonika, C., Papaventsis, D., Christaki, C., Priavali, E., Zotos, N., et al. (2009). Viral agents of acute gastroenteritis in hospitalized children in Greece. Clinical Microbiology and Infection, 15(6), 596-598. https://doi.org/10.111 1/j.1469-0691.2009.02855.x.

Lin, C. H., Wang, Y. Bin., Chen, S. H., Hsiung, C. A., \& Lin, C. Y. (2015). Precise genotyping and recombination detection of enterovirus. BMC Genomics, 16(12), S8. https://doi. org/10.1186/1471-2164-16-S12-S8.

Lin, J., \& Singh, A. (2015). Detection of human enteric viruses in Umgeni River, Durban, South Africa. Journal of Water and Health, 13(4), 1098-1112. https://doi.org/10.2166/wh.2015.238.

Lindberg, A. M., Andersson, P., Savolainen, C., Mulders, M. N., \& Hovi, T. (2003). Evolution of the genome of Human enterovirus $\mathrm{B}$ : incongruence between phylogenies of the VP1 and 3CD regions indicates frequent recombination within the species. Journal of General Virology, 84(5), 1223-1235. https://doi. org/10.1099/vir.0.18971-0.

Lion, T. (2014). Adenovirus infections in immunocompetent and immunocompromised patients. Clinical Microbiology Reviews, 27(3), 441-462. https://doi.org/10.1128/CMR.00116-13.

Lipp, E., \& Rose, J. (1997). The Role of Seafood in Foodborne Diseases in the United States of America. Revue Scientifique et Technique de l'OIE, 16(2), 20-640. https://doi.org/https://doi. org/10.20506/rst.16.2.1048

Liu, X., Jahuira, H., Gilman, R. H., Alva, A., Cabrera, L., Okamoto, M., et al. (2016). Etiological Role and Repeated Infections of Sapovirus among Children Aged Less than 2 Years in a Cohort Study in a Peri-urban Community of Peru Journal of Clinical Microbiology, 54(6), 1598-1604. https://doi.org/10.1128/ JCM.03133-15.

Lodder, W. J., Rutjes, S. A., Takumi, K., \& de Roda Husman, A. M. (2013). Aichi Virus in Sewage and Surface Water, the 
Netherlands. Emerging Infectious Diseases, 19(8), 1222-1230. https://doi.org/10.3201/eid1908.130312.

Lu, J., Sun, L., Fang, L., Yang, F., Mo, Y., Lao, J., et al. (2015). Gastroenteritis Outbreaks Caused by Norovirus GII.17, Guangdong Province, China, 2014-2015. Emerging Infectious Diseases, 21(7), 1240-1242. https://doi.org/https://doi.org/10.3201/eid21 07.150226

Lu, X., Chittaganpitch, M., Olsen, S. J., Mackay, I. M., Sloots, T. P., Fry, A. M., \& Erdman, D. D. (2006). Real-Time PCR Assays for Detection of Bocavirus in Human Specimens. Journal of Clinical Microbiology, 44(9), 3231-3235. https://doi.org/10.1128/ JCM.00889-06.

Lugo, D., \& Krogstad, P. (2016). Enteroviruses in the early 21 st century: New manifestations and challenges. Current Opinion in Pediatrics, 28(1), 107-113. https://doi.org/10.1016/j.physb eh.2017.03.040.

Lunestad, B. T., Maage, A., Roiha, I. S., Myrmel, M., Svanevik, C. S., \& Duinker, A. (2016). An outbreak of norovirus infection from shellfish soup due to unforeseen insufficient heating during preparation. Food and Environmental Virology, 8(4), 231-234. https://doi.org/10.1007/s12560-016-9245-5.

Lutterodt, G., van de Vossenberg, J., Hoiting, Y., Kamara, A. K., Oduro-Kwarteng, S., \& Foppen, J. W. A. (2018). Microbial groundwater quality status of hand-dug wells and boreholes in the Dodowa Area of Ghana. International Journal of Environmental Research and Public Health, 15(4), 1-12. https://doi. org/10.3390/ijerph15040730.

Mabasa, V. V., Meno, K. D., Taylor, M. B., \& Mans, J. (2018). Environmental Surveillance for Noroviruses in Selected South African Wastewaters 2015-2016: Emergence of the Novel GII.17. Food and Environmental Virology, 10(1), 16-28. https://doi.org/https ://doi.org/10.1007/s12560-017-9316-2

Magwalivha, M. (2009). The Molecular Characterisation of Human Adenoviruses from Human Specimens and Environmental Samples. University of Pretoria. http://repository.up.ac.za/bitstream/ handle/2263/28458/dissertation.pdf?sequence $=1$

Makhaola, K., Moyo, S., \& Kebaabetswe, L. P. (2020). Distribution and genetic variability of sapoviruses in Africa. Viruses, 12(490), 1-20. https://doi.org/10.3390/v12050490.

Mann, P., Pietsch, C., \& Liebert, U. G. (2019). Genetic diversity of sapoviruses among inpatients in Germany, 2008-2018. Viruses, 11(8), 1-14. https://doi.org/10.3390/v11080726.

Mans, J., Armah, G. E., Steele, A. D., \& Taylor, M. B. (2016). Norovirus Epidemiology in Africa: A Review. PLoS ONE, 11(4), 1-15. https://doi.org/10.1371/journal.pone.0146280.

Mans, J., Netshikweta, R., Magwalivha, M., Van Zyl, W. B., \& Taylor, M. B. (2013). Diverse norovirus genotypes identified in sewagepolluted river water in South Africa. Epidemiology and Infection, 141(2), 303-313. https://doi.org/10.1017/S0950268812000490.

Marie, V., \& Lin, J. (2017). Viruses in the environment - presence and diversity of bacteriophage and enteric virus populations in the Umhlangane River, Durban, South Africa. Journal of Water and Health, 15(6), 966-981. https://doi.org/10.2166/wh.2017.066.

Marx, F., Taylor, M., \& Grabow, W. (1995). Optimization of a PCR method for the detection of astrovirus type 1 in environmental samples. Water Science and Technology, 31(5), 359-362.

Masciopinto, C., De Giglio, O., Scrascia, M., Fortunato, F., La Rosa, G., Suffredini, E., et al. (2019). Human health risk assessment for the occurrence of enteric viruses in drinking water from wells: role of flood runoff injections. Science of the Total Environment, 666, 559-571. https://doi.org/10.1016/j.scitotenv.2019.02.107.

Mattioli, M. C., Boehm, A. B., Davis, J., Harris, A. R., Mrisho, M., \& Pickering, A. J. (2014). Enteric Pathogens in Stored Drinking Water and on Caregiver's Hands in Tanzanian Households With and Without Reported Cases of Child Diarrhea. PLOS ONE, 9(1). https://doi.org/https://doi.org/10.1371/journal.pone.0084939
Mattioli, M. C., Pickering, A. J., Gilsdorf, R. J., Davis, J., \& Boehm, A. B. (2013). Hands and water as vectors of diarrheal pathogens in Bagamoyo, Tanzania. Environmental Science and Technology, 47(1), 355-363. https://doi.org/10.1021/es303878d.

McKnight, K. L., \& Lemon, S. M. (2018). Hepatitis A Virus Genome Organization and Replication Strategy. Cold Spring Harbor perspectives in medicine, 8(12). https://doi.org/https://doi. org/10.1101/cshperspect.a033480

Medema, G., Heijnen, L., Elsinga, G., Italiaander, R., \& Brouwer, A. (2020). Presence of SARS-coronavirus-2 RNA in sewage and correlation with reported COVID-19 prevalence in the early stage of the epidemic in the Netherlands. Environmental Science \& Technology Letters, 7, 511-516. https://doi.org/10.1021/acs.estle tt.0c00357.

Meghnath, K., Hasselback, P., McCormick, R., Prystajecky, N., Taylor, M., McIntyre, L., et al. (2019). Outbreaks of norovirus and acute gastroenteritis associated with British Columbia Oysters, 2016-2017. Food and Environmental Virology, 11(2), 138-148. https://doi.org/10.1007/s12560-019-09374-4.

Mennechet, F. J. D., Paris, O., Ouoba, A. R., Salazar Arenas, S., Sirima, S. B., Takoudjou Dzomo, G. R., et al. (2019). A review of 65 years of human adenovirus seroprevalence. Expert Review of Vaccines, 18(6), 597-613. https://doi.org/10.1080/14760 584.2019.1588113.

Meqdam, M. M., \& Thwiny, I. R. (2007). Prevalence of group a rotavirus, enteric adenovirus, norovirus and astrovirus infections among children with acute gastroenteritis in Al-Qassim, Saudi Arabia. Pakistan Journal of Medical Sciences, 23(4), 551-555.

Momou, K. J., Akoua-Koffi, C., Traoré, K. S., Akré, D. S., \& Dosso, M. (2017). Effects of rainfalls variability and physical-chemical parameters on enteroviruses in sewage and lagoon in Yopougon, Côte d'Ivoire. Applied Water Science, 7(4), 2075-2087. https:// doi.org/10.1007/s13201-016-0388-1.

Muhammad, A., Hauwa, S., Elisha, P., Aminu, F., \& Nasir, I. (2020). Environmental Survey of Rotavirus in Sewage Water within Maiduguri Metropolis, Nigeria. Afro-Egyptian Journal of Infectious and Endemic Diseases, 10(2), 207-212. https://doi.org/https:// doi.org/10.21608/AEJI.2020.27901.1072

Murata, T., Katsushima, N., Mizuta, K., Muraki, Y., Hongo, S., \& Matsuzaki, Y. (2007). Prolonged Norovirus Shedding in Infants $\leq 6$ Months of Age with Gastroenteritis. Pediatric Infectious Disease Journal, 26(1), 46-49. https://doi.org/10.1097/01.inf.00002 47102.04997.e0.

Murray, T. Y., Mans, J., \& Taylor, M. B. (2013a). Human calicivirus diversity in wastewater in South Africa. Journal of Applied Microbiology, 114(6), 1843-1853. https://doi.org/10.1111/ jam.12167.

Murray, T. Y., Mans, J., \& Taylor, M. B. (2013b). First detection of human sapoviruses in river water in South Africa. Water Science and Technology, 67(12), 2776-2783. https://doi.org/10.2166/ wst.2013.203.

Murray, T. Y., Mans, J., van Zyl, W. B., \& Taylor, M. B. (2013c). Application of a competitive internal amplification control for the detection of sapoviruses in wastewater. Food and Environmental Virology, 5(1), 61-68. https://doi.org/10.1007/s1256 0-012-9101-1.

Murray, T. Y., \& Taylor, M. B. (2015). Quantification and molecular characterisation of human sapoviruses in water sources impacted by highly polluted discharged wastewater in South Africa. Journal of Water and Health, 13(4), 1055-1059. https:// doi.org/10.2166/wh.2015.255.

Muscillo, M., Fratini, M., Graffeo, R., Sanguinetti, M., Martella, V., Green, K. Y., et al. (2013). GIV Noroviruses in wastewaters and in stool specimens from hospitalized patients. Food and Environmental Virology, 5(4), 194-202. https://doi.org/10.1007/s1256 0-013-9121-5. 
Nadan, S., Walter, J. E., Grabow, W. O. K., Mitchell, D. K., \& Taylor, M. B. (2003). Molecular characterization of astroviruses by reverse transcriptase PCR and sequence analysis: Comparison of clinical and environmental isolates from South Africa. Applied and Environmental Microbiology, 69(2), 747-753. https://doi. org/10.1128/AEM.69.2.747-753.2003.

Nainan, O. V., Xia, G., Vaughan, G., \& Margolis, H. S. (2006). Diagnosis of hepatitis A virus infection: A molecular approach. Clinical Microbiology Reviews, 19(1), 63-79. https://doi.org/10.1128/ CMR.19.1.63.

Nakagawa-Okamoto, R., Arita-Nishida, T., Toda, S., Kato, H., Iwata, H., Akiyama, M., et al. (2009). Detection of multiple sapovirus genotypes and genogroups in oyster-associated outbreaks. Japanese Journal of Infectious Diseases, 62(1), 63-66.

Nasri, D., Bouslama, L., Pillet, S., Bourlet, T., Aouni, M., \& Pozzetto, B. (2007). Basic rationale, current methods and future directions for molecular typing of human enterovirus. Expert Review of Molecular Diagnostics, 7(4), 419-434. https ://doi.org/10.1586/14737159.7.4.419.

Navas, E., Torner, N., Broner, S., Godoy, P., Martínez, A., Bartolomé, R., \& Domínguez, A. (2015). Economic costs of outbreaks of acute viral gastroenteritis due to norovirus in Catalonia (Spain), 2010-2011. BMC Public Health, 15(1), 2-9. https ://doi.org/10.1186/s12889-015-2289-x.

Neiderud, C. J. (2015). How urbanization affects the epidemiology of emerging infectious diseases. African Journal of Disability, 5(1), 1-9. https://doi.org/10.3402/iee.v5.27060.

Nemudryi, A., Nemudraia, A., Wiegand, T., Surya, K., Buyukyoruk, M., Cicha, C., et al. (2020). Temporal detection and phylogenetic assessment of SARS-CoV-2 in municipal wastewater. Cell Reports Medicine, 1(6), 100098. https://doi.org/10.1016/j. xcrm.2020.100098.

Nenonen, N. P., Hernroth, B. H., Chauque, A. A., Hannoun, C., \& Bergstrom, T. (2006). Detection of hepatitis A virus genotype IB variants in clams from Maputo Bay, Mozambique. Journal of Medical Virology, 78, 52-55. https://doi.org/10.1002/jmv.

Nimgaonkar, I., Ding, Q., Schwartz, R. E., \& Ploss, A. (2018). Hepatitis E virus: Advances and challenges. Nature Reviews Gastroenterology Hepatology, 15, 96-110. https://doi.org/10.1038/nrgas tro.2017.150.

Nix, A. W., Oberste, M. S., \& Pallansch, M. A. (2006). Sensitive, seminested PCR amplification of VP1 sequences for direct identification of all enterovirus serotypes from original clinical specimens. Journal of Clinical Microbiology, 44(8), 2698-2704. https://doi. org/10.1128/JCM.00542-06.

Njuguna, J. (2016). Effect of eliminating open defecation on diarrhoeal morbidity: An ecological study of Nyando and Nambale subcounties, Kenya. BMC Public Health, 16(1), 2-7. https://doi. org/10.1186/s12889-016-3421-2.

Northill, J. A., Simmons, R. J., Genge, D., \& Moore, F. A. (2020). Molecular characterization of the first reported aichivirus A in Australia. Access Microbiology, 2, 1-7. https://doi.org/10.1099/ acmi.0.000099.

Oberste, M. S., Maher, K., Kilpatrick, D. R., Flemister, M. R., Brown, B. A., \& Pallansch, M. A. (1999a). Typing of human enteroviruses by partial sequencing of VP1. Journal of Clinical Microbiology, 37(5), 1288-1293. https://doi.org/10.1128/ jcm.37.5.1288-1293.1999.

Oberste, M. S., Maher, K., Kilpatrick, D. R., \& Pallansch, M. A. (1999b). Molecular evolution of the human enteroviruses: correlation of serotype with VP1 sequence and application to picornavirus classification. Journal of Virology, 73(3), 1941-8. https ://doi.org/10.1128/JVI.73.3.1941-1948.1999.

Ogorzaly, L., Walczak, C., Galloux, M., Etienne, S., Gassilloud, B., \& Cauchie, H. M. (2015). Human adenovirus diversity in water samples using a next-generation amplicon sequencing approach.
Food and Environmental Virology, 7(2), 112-121. https://doi. org/10.1007/s12560-015-9194-4.

Oh, D. Y., Silva, P. A., Hauroeder, B., Diedrich, S., Cardoso, D. D. P., \& Schreier, E. (2006). Molecular characterization of the first aichi viruses isolated in Europe and in South America. Archives of Virology, 151(6), 1199-1206. https://doi.org/10.1007/s0070 5-005-0706-7.

Oka, T., Wang, Q., Katayama, K., \& Saifb, L. J. (2015). Comprehensive review of human sapoviruses. Clinical Microbiology Reviews, 28(1), 32-53. https://doi.org/10.1128/CMR.00011-14.

Okoh, A. I., Sibanda, T., \& Gusha, S. S. (2010). Inadequately treated wastewater as a source of human enteric viruses in the environment. International Journal of Environmental Research and Public Health, 7(6), 2620-2637. https://doi.org/10.3390/ijerp h7062620.

Okubo, T., Iguchi, A., Tanaka, S., Uchida, S., Tagawa, T., Oshiki, M., et al. (2019). Health Impact of Agricultural Drainage Water for Farmers in the West Nile Delta. International Journal of Environmental Research, 13(2), 319-325. https://doi.org/10.1007/ s41742-019-00176-x.

Olaniran, A. O., Naidoo, S., \& Pillay, B. (2012). Surveillance of Invasive Bacterial Pathogens and Human Enteric Viruses in Wastewater Final Effluents and Receiving Water Bodies - a Case Study from Durban, South Africa. Clean - Soil, Air, Water, 40(7), 681691. https://doi.org/10.1002/clen.201100023.

Omosa, I. B., Wang, H., Cheng, S., \& Li, F. (2012). Sustainable tertiary wastewater treatment is required for water resources pollution control in Africa. Environmental Science and Technology, 46(13), 7065-7066. https://doi.org/10.1021/es3022254.

Ong, D. S. Y., Schuurman, R., \& Heikens, E. (2016). Human bocavirus in stool: A true pathogen or an innocent bystander? Journal of Clinical Virology, 74, 45-49. https://doi.org/10.1016/j. jcv.2015.11.027.

Onosi, O., Upfold, N. S., Jukes, M. D., Luke, G. A., \& Knox, C. (2019). The first molecular detection of aichi virus 1 in raw sewage and mussels collected in South Africa. Food and Environmental Virology, 11(1), 96-100. https://doi.org/10.1007/s1256 0-018-9362-4.

Onosi, O., Upfold, N. S., Jukes, M. D., Luke, G. A., \& Knox, C. (2020). The first detection of human bocavirus species 2 and 3 in raw sewage and mussels in South Africa. Food and Environmental Virology, 12(1), 84-88. https://doi.org/10.1007/s12560-01909417-w.

Opere, W. M. (2019). Detection of Pathogenic Human Adenoviruses and Enteroviruses in Water Samples Collected From Lake Victoria Along Homa Bay Town, Homa Bay. Kenyatta University. http://ir-library.ku.ac.ke/handle/123456789/19905

Oppong, T. B., Yang, H., Amponsem-Boateng, C., Kyere, E. K. D., Abdulai, T., Duan, G., \& Opolot, G. (2020). Enteric pathogens associated with gastroenteritis among children under 5 years in sub-Saharan Africa: A systematic review and meta-analysis. Epidemiology and Infection, 148(e64), 1-9. https://doi.org/10.1017/ S0950268820000618.

Osuolale, O., \& Okoh, A. (2015). Incidence of human adenoviruses and hepatitis A virus in the final effluent of selected wastewater treatment plants in Eastern Cape Province South Africa. Virology Journal, 12(1), 1-8. https://doi.org/10.1186/s12985-015-0327-z.

Osuolale, O., \& Okoh, A. (2017). Human enteric bacteria and viruses in five wastewater treatment plants in the Eastern Cape, South Africa. Journal of Infection and Public Health, 10(5), 541-547. https://doi.org/10.1016/j.jiph.2016.11.012.

Ouardani, I., Manso, C. F., Aouni, M., \& Romalde, J. L. (2015). Efficiency of hepatitis A virus removal in six sewage treatment plants from central Tunisia. Applied Microbiology and Biotechnology, 99(24), 10759-10769. https://doi.org/10.1007/s0025 3-015-6902-9. 
Owens, C. E. L., Angles, M. L., Cox, P. T., Byleveld, P. M., Osborne, N. J., \& Rahman, M. B. (2020). Implementation of quantitative microbial risk assessment (QMRA) for public drinking water supplies: Systematic review. Water Research, 174, 115614. https ://doi.org/10.1016/j.watres.2020.115614.

Paloniemi, M., Lappalainen, S., Salminen, M., Kätkä, M., Kantola, K., Hedman, L., et al. (2014). Human bocaviruses are commonly found in stools of hospitalized children without causal association to acute gastroenteritis. European Journal of Pediatrics, 173(8), 1051-1057. https://doi.org/10.1007/s00431-014-2290-x.

Papadopoulos, T., Klamer, S., Jacquinet, S., Catry, B., Litzroth, A., Mortgat, L., et al. (2019). The health and economic impact of acute gastroenteritis in Belgium, 2010-2014. Epidemiology and Infection, 147, 2010-2014. https://doi.org/10.1017/S095026881 900044X

Pavlov, D. N., Van Zyl, W. B., Van Heerden, J., Grabow, W. O. K., \& Ehlers, M. M. (2005). Prevalence of vaccine-derived polioviruses in sewage and river water in South Africa. Water Research, 39(14), 3309-3319. https://doi.org/10.1016/j.watre s.2005.05.027.

Pepe, T., Ventrone, I., Suffredini, E., Ceruso, M., Croci, L., Anastasio, A., \& Cortesi, M. L. (2012). Norovirus Monitoring in Bivalve Molluscs Harvested and Commercialized in Southern Italy. Journal of Food Protection, 75(5), 976-981. https://doi. org/10.4315/0362-028X.JFP-11-424.

Perera, D., Shimizu, H., Yoshida, H., Tu, P. Van., Ishiko, H., McMinn, P. C., \& Cardosa, M. J. (2010). A comparison of the VP1, VP2, and VP4 regions for molecular typing of human enteroviruses. Journal of Medical Virology, 82, 649-657. https://doi. org/10.1002/jmv.

Petrignani, M., Verhoef, L., de Graaf, M., Richardus, J. H., \& Koopmans, M. (2018). Chronic sequelae and severe complications of norovirus infection: A systematic review of literature. Journal of Clinical Virology, 105, 1-10. https://doi.org/10.1016/j. jcv.2018.05.004.

Pham, N. T. K., Khamrin, P., Nguyen, T. A., Kanti, D. S., Phan, T. G., Okitsu, S., \& Ushijima, H. (2007). Isolation and molecular characterization of aichi viruses from fecal specimens collected in Japan, Bangladesh, Thailand, and Vietnam. Journal of Clinical Microbiology, 45(7), 2287-2288. https://doi.org/10.1128/ JCM.00525-07.

Pichel, N., Vivar, M., \& Fuentes, M. (2019). The Problem of drinking water access: A review of disinfection technologies with an emphasis on solar treatment methods. Chemosphere, 218 , 1014-1030. https://doi.org/10.1016/j.chemosphere.2018.11.205.

Pina, S., Puig, M., Lucena, F., Jofre, J., \& Girones, R. (1998). Viral pollution in the environment and in shellfish: Human adenovirus detection by PCR as an index of human viruses. Applied and Environmental Microbiology, 64(9), 3376-3382.

Pintó, R. M., Alegre, D., Domíngueza, A., El-Senousy, W. M., Sánchez, G., Villena, C., et al. (2007). Hepatitis A virus in urban sewage from two mediterranean countries. Epidemiology and Infection, 135(2), 270-273. https://doi.org/10.1017/S0950268806006753.

Pires, S. M., Fischer-Walker, C. L., Lanata, C. F., Devleesschauwer, B., Hall, A. J., Kirk, M. D., et al. (2015). Aetiology-specific estimates of the global and regional incidence and mortality of diarrhoeal diseases commonly transmitted through food. PLOS ONE, 10(12), e0142927. https://doi.org/10.1371/journal.pone.0142927.

Platts-Mills, J. A., Babji, S., Bodhidatta, L., Gratz, J., Haque, R., Havt, A., et al. (2015). Pathogen-specific burdens of community diarrhoea in developing countries: A multisite birth cohort study (MAL-ED). The Lancet Global Health, 3(9), e564-e575. https ://doi.org/10.1016/S2214-109X(15)00151-5.

Polo, D. M., Vilariño, L., Manso, C. F., \& Romalde, J. L. (2010). Imported mollusks and dissemination of human enteric viruses.
Emerging Infectious Diseases, 16(6), 1036-1038. https://doi. org/10.3201/eid1606.091748.

Potasman, I., Paz, A., \& Odeh, M. (2002). Infectious outbreaks associated with bivalve shellfish consumption: A worldwide perspective. Clinical Infectious Diseases, 35(8), 921-928. https://doi. org/10.1086/342330.

Potgieter, N., Karambwe, S., Mudau, L. S., Barnard, T., \& Traore, A. (2020). Human Enteric Pathogens in Eight Rivers Used as Rural Household Drinking Water Sources in the Northern Region of South Africa. International Journal of Environmental Research and Public Health, 17(6). https://doi.org/https://doi.org/10.3390/ ijerph17062079

Prado, T., de Castro Bruni, A., Barbosa, M. R. F., Garcia, S. C., de Jesus Melo, A. M., \& Sato, M. I. Z. (2019). Performance of wastewater reclamation systems in enteric virus removal. Science of the Total Environment, 678, 33-42. https://doi.org/10.1016/j. scitotenv.2019.04.435.

Prez, V. E., Poma, H. R., Giordano, G. G., Victoria, M., Nates, S. V., Rajal, V. B., \& Barril, P. A. (2020). Rotavirus contamination of surface waters from the northwest of Argentina. Journal of Water and Health, 18(3), 409-415. https://doi.org/10.2166/ wh.2020.005.

Puenpa, J., Wanlapakorn, N., Vongpunsawad, S., \& Poovorawan, Y. (2019). The History of Enterovirus A71 Outbreaks and Molecular Epidemiology in the Asia-Pacific Region. Journal of Biomedical Science, 26(1), 1-11. https://doi.org/10.1186/s1292 9-019-0573-2.

Qiu, Y., Lee, B. E., Neumann, N., Ashbolt, N., Craik, S., Maal-Bared, R., \& Pang, X. L. (2015). Assessment of human virus removal during municipal wastewater treatment in Edmonton, Canada. Journal of Applied Microbiology, 119(6), 1729-1739. https:// doi.org/10.1111/jam.12971.

Rachida, S., Matsapola, P. N., Wolfaardt, M., \& Taylor, M. B. (2016). Genetic characterization of a novel hepatitis A virus strain in irrigation water in South Africa. Journal of Medical Virology, 88, 734-737. https://doi.org/10.1002/jmv.24370.

Rajtar, B., Majek, M., Polański, Ł, \& Polz-Dacewicz, M. (2008). Enteroviruses in water environment - a potential threat to public health. Annals of Agricultural and Environmental Medicine, 15(2), 199-203.

Rehnstam-Holm, A. A., \& Hernroth, B. (2005). Shellfish and Public Health: A Swedish Perspective. Royal Swedish Academy of Sciences, 34(2), 139-144.

Rheingans, R. D., Antil, L., Dreibelbis, R., Podewils, L. J., Bresee, J. S., \& Parashar, U. D. (2009). Economic costs of rotavirus gastroenteritis and cost-effectiveness of vaccination in developing countries. Journal of Infectious Diseases, 200, S16-27. https:// doi.org/10.1086/605026.

Rice, M. (2001). Environmental Impacts of Shellfish Aquaculture: Filter Feeding to Control Eutrophication. In M. Tlusty, H. Bengtson, H. Halvorsen, S. Oktay, J. Pearce, \& R. Rheualt (Eds.), Marine Aquaculture and the Marine Environment: A Meeting for the Stakeholders in the Northeast (pp. 77-86). Falmouth, MA: Cape Cod Press.

Richards, G. (2016). Shellfish-Associated Enteric Virus Illness: Virus Localization, Disease Outbreaks and Prevention. In S. M. Goyal \& J. L. Cannon (Eds.), Viruses in Foods. Food Microbiology and Food Safety (pp. 471-503). Cham: Springer. https://doi.org/https ://doi.org/10.1007/978-3-319-30723-7

Rivadulla, E., \& Romalde, J. L. (2020). A Comprehensive Review on Human Aichi Virus. Virologica Sinica. https://doi.org/10.1007/ s12250-020-00222-5.

Rivadulla, E., Varela, M. F., \& Romalde, J. L. (2019). Epidemiology of Aichi Virus In Fecal Samples From Outpatients With Acute Gastroenteritis in Northwestern Spain. Journal of Clinical Virology, 118, 14-19. https://doi.org/10.1016/j.jcv.2019.07.011. 
Rizk, N. M., \& Allayeh, A. K. (2018). Multiplex semi-nested RT-PCR for genotyping of rotaviruses group A in Giza tap water Egypt. Asian Journal of Water, Environment and Pollution, 15(2), 217221. https://doi.org/10.3233/AJW-180034.

Rizk, N. M., \& Allayeh, A. K. (2020). Genotyping of Rotaviruses in River Nile in Giza, Egypt. Iranian Journal of Public Health, 49(1), 173-180.

Rodríguez, R. A., Pepper, I. L., \& Gerba, C. P. (2009). Application of PCR-based methods to assess the infectivity of enteric viruses in environmental samples. Applied and Environmental Microbiology, 75(2), 297-307. https://doi.org/10.1128/AEM.01150-08.

Romalde, J. L., Rivadulla, E., Varela, M. F., \& Barja, J. (2017). An Overview of 20 years of studies on the prevalence of human enteric viruses in shellfish from Galicia Spain. Journal of Applied Microbiology, 124(4), 943-957. https://doi.org/10.1111/ ijlh.12426.

Royston, L., Geiser, J., Josset, L., Schuffenecker, I., \& Tapparel, C. (2017). A new real-time RT-PCR targeting VP4-VP2 to detect and quantify enterovirus D68 in respiratory samples. Journal of Medical Virology, 89(10), 1879-1881. https://doi.org/10.1002/ jmv.24778.

Sadik, N. (2016). Quantification of Multiple Waterborne Pathogens in Drinking Waters, Drainage Channels, And Surface Waters in Kampala, Uganda Over Seven Months of Seasonal Variation. University of Illinois at Urbana-Champaign. http://hdl.handl e.net/2142/92860

Saïd, R., Wolfaardt, M., \& Taylor, M. B. (2014). Molecular characterisation of hepatitis A virus strains from water sources in South Africa. Water Science and Technology, 69(5), 923-933. https:// doi.org/10.2166/wst.2013.799.

Sánchez, G., \& Bosch, A. (2016). Survival of Enteric Viruses in the Environment and Food. In S. M. Goyal \& J. L. Cannon (Eds.), Viruses in Foods (pp. 367-392). Cham: Springer International Publishing. https://doi.org/10.1007/978-3-319-30723-7_13.

Sdiri-Loulizi, K., Hassine, M., Aouni, Z., Gharbi-Khelifi, H., Chouchane, S., Sakly, N., et al. (2010a). Detection and molecular characterization of enteric viruses in environmental samples in Monastir, Tunisia between January 2003 and April 2007. Journal of Applied Microbiology, 109(3), 1093-1104. https://doi.org/10. 1111/j.1365-2672.2010.04772.x.

Sdiri-Loulizi, K., Hassine, M., Aouni, Z., Gharbi-Khelifi, H., Sakly, N., Chouchane, S., et al. (2010b). First molecular detection of Aichi virus in sewage and shellfish samples in the Monastir region of Tunisia. Archives of Virology, 155(9), 1509-1513. https://doi. org/10.1007/s00705-010-0744-7.

Sdiri-Loulizi, K., Hassine, M., Gharbi-Khelifi, H., Sakly, N., Chouchane, S., Guediche, M. N., et al. (2009). Detection and Genomic Characterization of Aichi Viruses in Stool Samples from Children in Monastir, Tunisia. Journal of Clinical Microbiology, 47(7), 2275-2278. https://doi.org/10.1128/JCM.00913-09.

Seitz, S. R., Leon, J. S., Schwab, K. J., Lyon, G. M., Dowd, M., McDaniels, M., et al. (2011). Norovirus Infectivity in Humans and Persistence in Water. Applied and Environmental Microbiology, 77(19), 6884-6888. https://doi.org/10.1128/AEM.05806-11.

Sekwadi, P. G., Ravhuhali, K. G., Mosam, A., Essel, V., Ntshoe, G. M., Shonhiwa, A. M., et al. (2018). Waterborne outbreak of gastroenteritis on the KwaZulu-Natal Coast, South Africa, December 2016/January 2017. Epidemiology and Infection, 146(10), 1318-1325. https://doi.org/10.1017/S095026881800122X.

Shaheen, M. N. F., Abd El-Daim, S. E., Ahmed, N. I., \& Elmahdy, E. M. (2018a). Molecular detection of three gastroenteritis viruses in an urban sewage treatment plant and river water in Egypt. Egyptian Journal of Aquatic Biology and Fisheries, 22(5 Special Issue), 615-627. https://doi.org/https://doi.org/10.21608/ ejabf. 2018.60278
Shaheen, M. N. F., Abdel-Daim, S. E., Ahmed, N. I., \& Elmahdy, E. M. (2019a). Environmental monitoring of Aichi virus and human bocavirus in samples from wastewater treatment plant, drain, and River Nile in Egypt. Journal of Water and Health, 18(1), 30-37. https://doi.org/10.2166/wh.2019.075.

Shaheen, M. N. F., \& Elmahdy, E. M. (2019). Environmental monitoring of astrovirus and norovirus in the Rosetta branch of the River Nile and the El-Rahawy drain, Egypt. Water Science and Technology: Water Supply, 19(5), 1381-1387. https://doi. org/10.2166/ws.2019.004.

Shaheen, M. N. F., Elmahdy, E. M., \& Chawla-Sarkar, M. (2019b). Quantitative PCR-based identification of enteric viruses contaminating fresh produce and surface water used for irrigation in Egypt. Environmental Science and Pollution Research, 26(21), 21619-21628. https://doi.org/10.1007/s11356-019-05435-0.

Shastri, S., Doane, A. M., Gonzales, J., Upadhyayula, U., \& Bass, D. M. (1998). Prevalence of Astroviruses in a Children's Hospital. Journal of Clinical Microbiology, 36(9), 2571-2574. https://doi. org/10.1128/jcm.36.9.2571-2574.1998.

Sibanda, T., Chigor, V. N., \& Okoh, A. I. (2013). Seasonal and spatio-temporal distribution of faecal-indicator bacteria in Tyume River in the Eastern Cape Province, South Africa. Environmental Monitoring and Assessment, 185(8), 6579-6590. https://doi. org/10.1007/s10661-012-3048-4.

Sibanda, T., \& Okoh, A. I. (2012). Assessment of the incidence of enteric adenovirus species and serotypes in surface waters in the Eastern Cape Province of South Africa: Tyume River as a Case Study. The Scientific World Journal, 2012, 949216. https://doi. org/10.1100/2012/949216.

Sibanda, T., \& Okoh, A. I. (2013). Real-time PCR quantitative assessment of hepatitis A virus, rotaviruses and enteroviruses in the Tyume River located in the Eastern Cape Province, South Africa. Water SA, 39(2), 295-304. https://doi.org/10.4314/wsa.v39i2.14.

Sibanda, T., Selvarajan, R., \& Tekere, M. (2015). Urban effluent discharges as causes of public and environmental health concerns in South Africa's aquatic milieu. Environmental Science and Pollution Research, 22(23), 18301-18317. https://doi.org/10.1007/ s11356-015-5416-4.

Sidhu, J. P. S., Sena, K., Hodgers, L., Palmer, A., \& Toze, S. (2018). Comparative enteric viruses and coliphage removal during wastewater treatment processes in a sub-tropical environment. Science of the Total Environment, 616-617, 669-677. https://doi. org/10.1016/j.scitotenv.2017.10.265.

Siebenga, J. J., Vennema, H., Zheng, D. P., Vinjé, J., Bonita, E., Lee, X. L. P., et al. (2009). Norovirus Illness is a Global Problem: Emergence and Spread of Norovirus GII.4 Variants, 2001-2007. Journal of Infectious Diseases, 200(5), 802-812. https://doi. org/10.1086/605127.

Silverman, A. I., Nelson, K. L., Akrong, M. O., Amoah, P., \& Drechsel, P. (2013). Quantification of human norovirus GII, human adenovirus, and fecal indicator organisms in wastewater used for irrigation in Accra, Ghana. Journal of Water and Health, 11(3), 473-488. https://doi.org/10.2166/wh.2013.025.

Sinclair, R. G., Jones, E. L., \& Gerba, C. P. (2009). Viruses in recreational water-borne disease outbreaks: A review. Journal of Applied Microbiology, 107(6), 1769-1780. https://doi.org/10.1 111/j.1365-2672.2009.04367.x.

Singh, A. (2012). Surveillance of Microbial Pathogens in the Umgeni River, Durban South Africa. University of KwaZulu-Natal. http:// hdl.handle.net/10413/10070.

Smith, D. B., \& Simmonds, P. (2018). Classification and Genomic Diversity of Enterically Transmitted Hepatitis Viruses. Cold Spring Harbor Perspectives in Medicine, 8(9), 1-16. https://doi. org/10.1101/cshperspect.a031880. 
Smuts, H., Cronje, S., Thomas, J., Brink, D., Korsman, S., \& Hardie, D. (2018). Molecular characterization of an outbreak of enterovirusassociated meningitis in Mossel Bay, South Africa, December 2015-January 2016. BMC Infectious Diseases, 18(1), 1-11. https ://doi.org/10.1186/s12879-018-3641-4.

Söderlund-Venermo, M. (2019). Emerging Human Parvoviruses: The Rocky Road to Fame. Annual Review of Virology, 6(1), 71-91. https://doi.org/10.1146/annurev-virology-092818-015803.

Supadej, K., Khamrin, P., Kumthip, K., Malasao, R., Chaimongkol, N., Saito, M., et al. (2019). Distribution of Norovirus and Sapovirus Genotypes with Emergence of NoV GII.P16/GII.2 Recombinant Strains in Chiang Mai, Thailand. Journal of Medical Virology, 91(2), 215-224. https://doi.org/https://doi.org/10.1002/ jmv.25261

Taghinejad, M., Ghaderi, M., \& Mousavi-Nasab, S. D. (2020). High frequency of aichivirus in children with acute gastroenteritis in Iran. The Pediatric Infectious Disease Journal, 39(7), 576-579. https://doi.org/10.1097/inf.0000000000002638.

Takahashi, M., Tanaka, T., Azuma, M., Kusano, E., Aikawa, T., Shibayama, T., et al. (2007). Prolonged Fecal Shedding of Hepatitis E Virus (HEV) during Sporadic Acute Hepatitis E: Evaluation of Infectivity of HEV in Fecal Specimens in a Cell Culture System. Journal of Clinical Microbiology, 45(11), 3671-3679. https://doi.org/10.1128/JCM.01086-07.

Tang, J. W., \& Holmes, C. W. (2017). Acute and chronic disease caused by enteroviruses. Virulence, 8(7), 1062-1065. https:// doi.org/10.1080/21505594.2017.1308620.

Tate, J. E., Burton, A. H., Boschi-Pinto, C., Parashar, U. D., Agocs, M., Serhan, F., et al. (2016). Global, Regional, and National Estimates of Rotavirus Mortality in Children $<5$ Years of Age, 2000-2013. Clinical Infectious Diseases, 62(Suppl 2), S96S105. https://doi.org/10.1093/cid/civ1013.

Taylor, M. B., Cox, N., Vrey, M. A., \& Grabow, W. O. K. (2001). The occurrence of hepatitis A and astroviruses in selected river and dam waters in South Africa. Water Research, 35(11), 2653-2660. https://doi.org/10.1016/S0043-1354(00)00551-0.

Teixeira, D. M., Hernandez, J. M., Silva, L. D., de Oliveira, D., de Spada, P. K., Gurjão, T. C. M., et al. (2016). Occurrence of Norovirus GIV in Environmental Water Samples from Belém City, Amazon Region, Brazil. Food and Environmental Virology, 8(1), 101-104. https://doi.org/10.1007/s1256 0-015-9220-6.

Trivedi, T. K., Desai, R., Hall, A. J., Patel, M., Parashar, U. D., \& Lopman, B. A. (2013). Clinical characteristics of norovirusassociated deaths: A systematic literature review. American Journal of Infection Control, 41(7), 654-657. https://doi. org/10.1016/j.ajic.2012.08.002.

Troeger, C., Khalil, I. A., Rao, P. C., Cao, S., Blacker, B. F., Ahmed, T., et al. (2018). Rotavirus Vaccination and the Global Burden of Rotavirus Diarrhea Among Children Younger Than 5 Years. JAMA Pediatrics, 172(10), 958-965. https://doi.org/10.1001/ jamapediatrics.2018.1960.

UNESCO. (2019). The United Nations World Water Development Report 2019: Leaving no one behind. UNESCO Digital Library. Paris. https://doi.org/10.1037//0033-2909.I26.1.78

Van Abel, N., \& Taylor, M. B. (2018). The Use of Quantitative Microbial Risk Assessment to Estimate the Health Risk from Viral Water Exposures in sub-Saharan Africa: A review. Microbial Risk Analysis, 8(November 2017), 32-49. https:// doi.org/https://doi.org/10.1016/j.mran.2017.12.001

van Heerden, J., Ehlers, M. M., \& Grabow, W. O. K. (2005a). Detection and risk assessment of adenoviruses in swimming pool water. Journal of Applied Microbiology, 99(5), 1256-1264. https://doi.org/10.1111/j.1365-2672.2005.02607.x.

van Heerden, J., Ehlers, M. M., Heim, A., \& Grabow, W. O. K. (2005b). Prevalence, quantification and typing of adenoviruses detected in river and treated drinking water in South Africa. Journal of Applied Microbiology, 99(2), 234-242. https://doi. org/10.1111/j.1365-2672.2005.02617.x.

van Heerden, J., Ehlers, M. M., Van Zyl, W. B., \& Grabow, W. O. K. (2003). Incidence of adenoviruses in raw and treated water. Water Research, 37, 3704-3708. https://doi.org/10.1016/S0043 $-1354(03) 00245-8$.

van Heerden, J., Ehlers, M. M., van Zyl, W. B., \& Grabow, W. O. K. (2004). Prevalence of human adenoviruses in raw and treated water. Water Science and Technology, 50(1), 39-43. https:// doi.org/10.2166/wst.2004.0013.

van Zyl, W. B., Page, N. A., Grabow, W. O. K., Steele, A. D., \& Taylor, M. B. (2006). Molecular Epidemiology of Group A Rotaviruses in Water Sources and Selected Raw Vegetables in Southern Africa. Applied and Environmental Microbiology, 72(7), 4554-4560. https://doi.org/10.1128/AEM.02119-05.

van Zyl, W. B., Williams, P. J., Grabow, W. O. K., \& Taylor, M. B. (2004). Application of a molecular method for the detection of group A rotaviruses in raw and treated water. Water Science and Technology, 50(1), 223-228. https://doi.org/10.2166/ wst.2004.0058.

van Zyl, W. B., Zhou, N. A., Wolfaardt, M., Matsapola, P. N., Ngwana, F. B., Symonds, E. M., et al. (2019). Detection of potentially pathogenic enteric viruses in environmental samples from kenya using the bag-mediated filtration system. Water Science and Technology: Water Supply, 19(6), 1668-1676. https://doi. org/10.2166/ws.2019.046.

Varela, M. F., Ouardani, I., Kato, T., Kadoya, S., Aouni, M., Sano, D., \& Romaldea, J. I. (2018). Sapovirus in Wastewater Treatment Plants in Tunisia: Prevalence, Removal, and Genetic Characterization. Applied and Environmental Microbiology, 84(6), 1-11.

Varela, M. F., Rivadulla, E., Lema, A., \& Romalde, J. L. (2019). Human Sapovirus Among Outpatients with Acute Gastroenteritis in Spain: A One-Year Study. Viruses. https://doi.org/10.3390/ v11020144.

Vellinga, J., Van der Heijdt, S., \& Hoeben, R. C. (2005). The Adenovirus capsid: major progress in minor proteins. Journal of General Virology, 86(6), 1581-1588. https://doi.org/10.1099/vir.0.80877 -0 .

Verheyen, J., Timmen-Wego, M., Laudien, R., Boussaad, I., Sen, S., Koc, A., et al. (2009). Detection of Adenoviruses and Rotaviruses in Drinking Water Sources Used In Rural Areas of Benin, West Africa. Applied and Environmental Microbiology, 75(9), 2798-2801. https://doi.org/10.1128/AEM.01807-08.

Viarengo, A., \& Canesi, L. (1991). Mussels as biological indicators of pollution. Aquaculture, 94(2-3), 225-243. https://doi. org/10.1016/0044-8486(91)90120-V.

Villena, C., El-Senousy, W. M., Abad, F. X., Pintó, R. M., \& Bosch, A. (2003). Group A Rotavirus in Sewage Samples from Barcelona and Cairo: Emergence of Unusual Genotypes. Applied and Environmental Microbiology, 69(7), 3919-3923. https://doi. org/10.1128/AEM.69.7.3919-3923.2003.

Vinjé, J. (2015). Advances in Laboratory Methods for Detection and Typing of Norovirus. Journal of Clinical Microbiology, 53(2), 373-381. https://doi.org/10.1128/JCM.01535-14.

Vivier, J. C., Ehlers, M. M., \& Grabow, W. O. K. (2004). Detection of enteroviruses in treated drinking water. Water Research, 38(11), 2699-2705. https://doi.org/10.1016/S0043-1354(01)00433-X.

Vos, H. J., \& Knox, C. M. (2018). The recovery and molecular identification of HAdV-D17 in raw sewage and mussel samples collected in the Eastern Cape Province of South Africa. Southern African Journal of Infectious Diseases, 33(1), 4-7. https://doi. org/10.4102/sajid.v33i1.27.

Vu, D. L., Bosch, A., Pintó, R. M., \& Guix, S. (2017). Epidemiology of Classic and Novel Human Astrovirus: Gastroenteritis and Beyond. Viruses, 9(2), 1-23. https://doi.org/10.3390/v9020033. 
Vu, D. L., Cordey, S., Brito, F., \& Kaiser, L. (2016). Novel human astroviruses: Novel human diseases? Journal of Clinical Virology, 82, 56-63. https://doi.org/10.1016/j.jcv.2016.07.004.

Wagner, J. C., Pyles, R. B., Miller, A. L., Nokso-Koivisto, J., Loeffelholz, M. J., \& Chonmaitree, T. (2016). Determining Persistence of Bocavirus DNA in the Respiratory Tract of Children by Pyrosequencing. Pediatric Infectious Disease Journal, 35(5), 471-476. https://doi.org/10.1097/INF.0000000000001058.

Wang, H., Naghavi, M., Allen, C., Barber, R. M., Carter, A., Casey, D. C., et al. (2016). Global, regional, and national life expectancy, all-cause mortality, and cause-specific mortality for 249 causes of death, 1980-2015: A systematic analysis for the Global Burden of Disease Study 2015. The Lancet, 388(10053), 1459-1544. https://doi.org/10.1016/S0140-6736(16)31012-1.

Wang, H., Wang, T., Zhang, B., Li, F., Toure, B., Omosa, I. B., et al. (2014). Water and Wastewater Treatment in Africa - Current Practices and Challenges. Clean - Soil, Air, Water, 42(8), 10291035. https://doi.org/10.1002/clen.201300208.

Weimann, A., \& Oni, T. (2019). A Systematised Review of the Health Impact of Urban Informal Settlements and Implications for Upgrading Interventions in South Africa, a Rapidly Urbanising Middle-Income Country. International Journal of Environmental Research and Public Health, 16(19), 1-17. https://doi. org/10.3390/ijerph16193608.

Wells, A. I., \& Coyne, C. B. (2019). Enteroviruses: A Gut-Wrenching Game of Entry, Detection, and Evasion. Viruses, 11(5), 1-20. https://doi.org/10.3390/v11050460.

Westrell, T., Dusch, V., Ethelberg, S., Harris, J., Hjertqvist, M., da Silva, N. J., et al. (2010). Norovirus outbreaks linked to oyster consumption in the United Kingdom, Norway, France, Sweden and Denmark, 2010. Eurosurveillance, 15(12), 7-10. https://doi. org/10.2807/ese.15.12.19524-en.

WHO. (2017). Global Hepatitis Report 2017. Geneva.

WHO, UNICEF, \& JMP. (2019). Progress on Household Drinking Water, Sanitation and Hygiene 2000-2017. Special Focus on Inequalities. United Nations Children's Fund (UNICEF) and World Health Organization. New York. https://washdata.org/ sites/default/files/documents/reports/2019-07/jmp-2019-washhouseholds.pdf

Wohlgemuth, N., Honce, R., \& Schultz-Cherry, S. (2019). Astrovirus evolution and emergence. Infection, Genetics and Evolution, 69, 30-37. https://doi.org/10.1016/j.meegid.2019.01.009.

Woods, J. W., Calci, K. R., Marchant-Tambone, J. G., \& Burkhardt, W. (2016). Detection and molecular characterization of norovirus from oysters implicated in outbreaks in the US. Food Microbiology, 59, 76-84. https://doi.org/10.1016/j.fm.2016.05.009.

Wu, F., Xiao, A., Zhang, J., Gu, X., Lee, W., Kauffman, K., et al. (2020). SARS-CoV-2 Titers in Wastewater are Higher Than Expected from Clinically Confirmed Cases. mySystems, 5(4), e00614-20. https://doi.org/https://doi.org/10.1128/mSyst ems.00614-20.

WWAP \& UNESCO. (2017). The United Nations World Water Development Report 2017. Wastewater: The Untapped Resource. Paris. https://doi.org/10.1017/CBO9781107415324.004.
Yamashita, T., Kobayashi, S., Sakae, K., Nakata, S., Chiba, S., Ishihara, Y., \& Isomura, S. (1991). Isolation of Cytopathic Small Round Viruses with BS-C-1 Cells from Patients with Gastroenteritis. Journal of Infectious Diseases, 164(5), 954-957. https://doi. org/10.1093/infdis/164.5.954.

Yamashita, T., Sugiyama, M., Tsuzuki, H., Sakae, K., Suzuki, Y., \& Miyazaki, Y. (2000). Application of a Reverse TranscriptionPCR for Identification and Differentiation of Aichi Virus, a New Member of the Picornavirus Family Associated with Gastroenteritis in Humans. Journal of Clinical Microbiology, 38(8), 2955-2961. https://doi.org/10.1128/jcm.38.8.2955-2961.2000.

Yang, S., Zhang, W., Shen, Q., Yang, Z., Zhu, J., Cui, L., \& Hua, X. (2009). Aichi Virus Strains in Children with Gastroenteritis, China. Emerging Infectious Diseases, 15(10), 1703-1705. https ://doi.org/10.1086/522125.

Yezli, S., \& Otter, J. A. (2011). Minimum Infective Dose of the Major Human Respiratory and Enteric Viruses Transmitted Through Food and the Environment. Food and Environmental Virology, 3(1), 1-30. https://doi.org/10.1007/s12560-011-9056-7.

Yoneda, M., Nakano, M., Sugimoto, D., Inada, M., Fujitani, M., \& Kitahori, Y. (2017). Epidemiological Characteristics of Sapovirus and Human Astrovirus Detected among Children in Nara Prefecture, Japan, during the 2009/2010-2014/2015 Seasons. Japanese Journal of Infectious Diseases, 70(1), 87-91. https:// doi.org/10.7883/yoken.JJID.2015.529.

Yotsuyanagi, H., Koike, K., Yasuda, K., Moriya, K., Shintani, Y., Fujie, H., et al. (1996). Prolonged fecal excretion of hepatitis A virus in adult patients with hepatitis a as determined by polymerase chain reaction. Hepatology, 24(1), 10-13. https://doi.org/10.1053/ jhep.1996.v24.pm0008707246.

Zhou, F., Kong, F., Wang, B., McPhie, K., Gilbert, G. L., \& Dwyer, D. E. (2011). Molecular characterization of enterovirus 71 and coxsackievirus A16 using the 5' untranslated region and VP1 region. Journal of Medical Microbiology, 60(3), 349-358. https ://doi.org/10.1099/jmm.0.025056-0.

Zhou, X., Kong, D. G., Li, J., Pang, B. B., Zhao, Y., Zhou, J. B., et al. (2019). An Outbreak of Gastroenteritis Associated with GII.17 Norovirus-Contaminated Secondary Water Supply System in Wuhan, China, 2017. Food and Environmental Virology, 11(2), 126-137. https://doi.org/10.1007/s12560-019-09371-7.

Zormati, S., Kallel, I., Sellami, H., \& Gdoura, R. (2018). Influence of Environmental and Seasonal Factors on Microbial Contamination Levels in Clam Production Areas in Southern Tunisia: Escherichia coli, Salmonella spp., Hepatitis A Virus and Norovirus. Revue scientifique et technique (International Office of Epizootics), 37(3), 1061-1070. https://doi.org/https://doi. org/10.20506/rst.37.3.2906.

Publisher's Note Springer Nature remains neutral with regard to jurisdictional claims in published maps and institutional affiliations. 